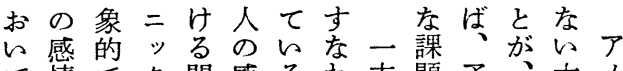

て情でク問感るわ方題了、大メ

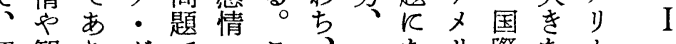

個観りグで・と、マなり祭なカ

人念、ルあ観の社イつ力政社の

のと全 でる念よ会ノてで治而

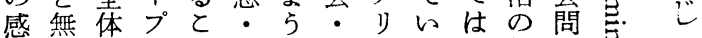

情関的へと理 $飞$ 政テるマ指題す

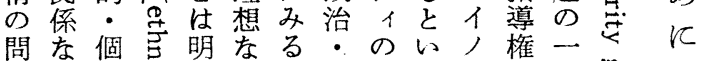

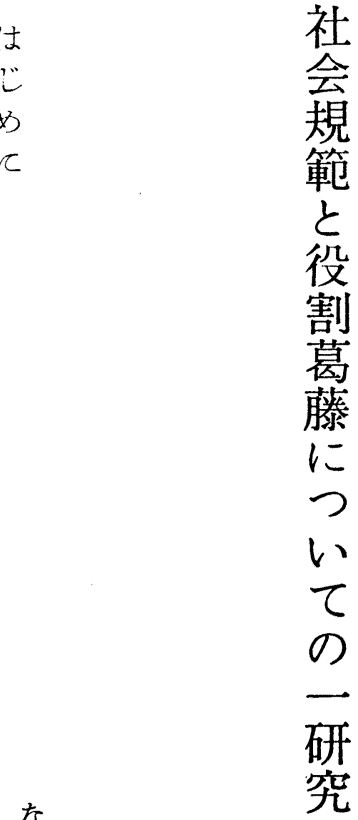

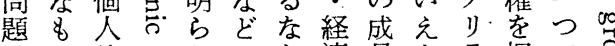

はの的骂かの占済員よテ握で导

社し具导市題面面

会や体りるを現飞完問め。問

学す的の $と$ 在 お全題の自題

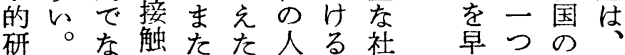

究従品法種平会急の民現

反っと、異律問等統 $儿$ 前主在

とてと部うや題の合解提化で

っ文分た社の権的決ををは

て人的人会現利吕 寸度完簢

は種人、種政実の光つ全単

格関種非や策的獲

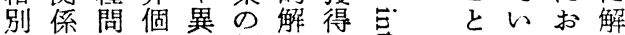

対の題人弓領決を范㤎ると決

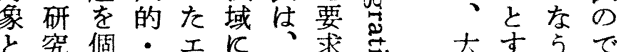

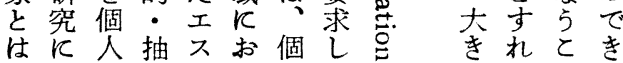

にびす 異でい

今理 5

てた論安

お問やで

り 題 調 \&

そで查な

と研く題

当究、設

は今相今社定

容早コ統

れのン合

がアトお

たメ、よ

เリス び

さ力ぺ社

ざ社ン会

ま壮了制

な以以

集人来。

団種 社吕.

規や会

範 文学 者

存の者寻

在上注 $\triangleq$

しで目

て非をと

的常あ関

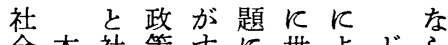
会本社策すに世よドら 規稿会が力つ論つミな

II 範は主、といにてナい と社なてょ維ンの のと適会るのつ持トで 関の合構の民てさ・あ 係ら老造で主達れグる を可のあ的成左几 社䧴能なる。さ雄! 会觀反か。法れさプ 統点する゙こ律ねれと の前の機よ政ないイ 面提で的 5 策らる, かとあになの妨り らてる作世成とと, テ

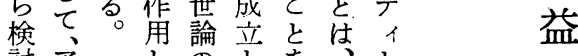

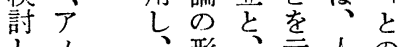
Lメ、形示人の ょり個式そし種関

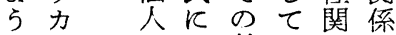
と飞と效的係が すお集つ果るの る 団て的。民法 のる の統法施論主律や で種—律行はが社 あ問、やを人必会 る題 集社 亏種然政 固会な問的策
岡

実 


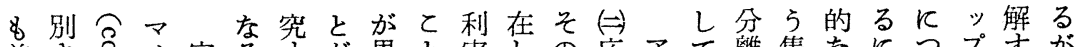

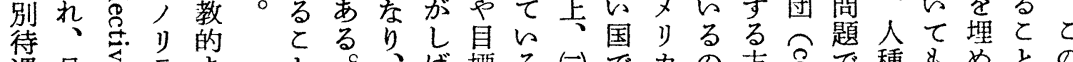

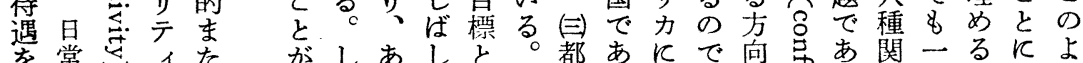

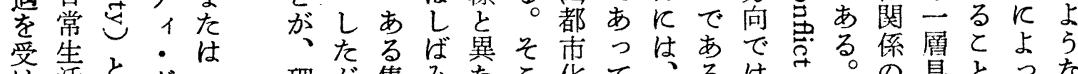
け活とグ歴理が集みなと化ているはな具とっな

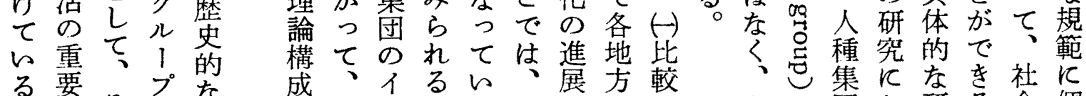

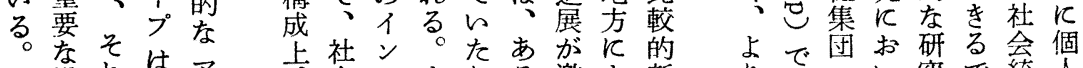

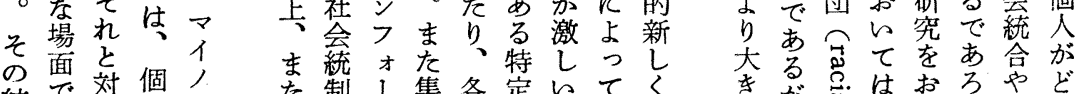

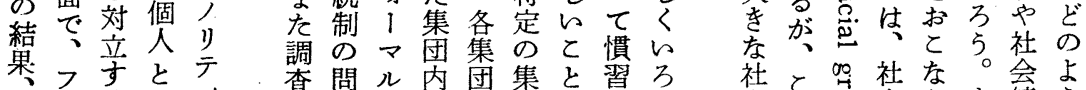

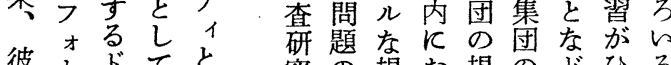
彼、ドてと究の規お規のどひろ

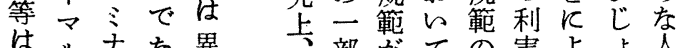
はルナな異部がての害よょ人

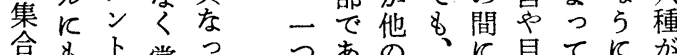

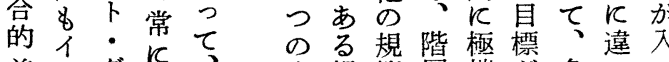
差ングにて 有規範層端が多等っ 別フルう人意範とにな倳てて やオ 偏プの種義の茅よ相全な速集るた

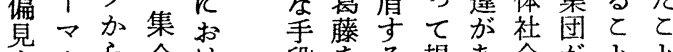
をルら合け段をる嫢あ会がとと 5 飞区体る 社と会社な な@合と従 か名は、㟔そ理つ 飞气差でれ論て 統古根別き飞とい 合の本やるよ調る 委過的偏とっ 查加 る程に見考七方を

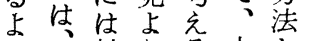
5 対りる人と正 に集立\&。種のし 作団し根要関ギく 用を合本守係ヤ理

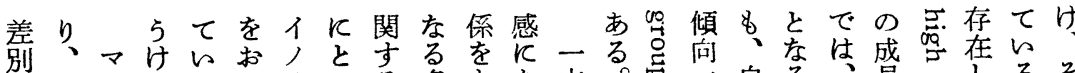

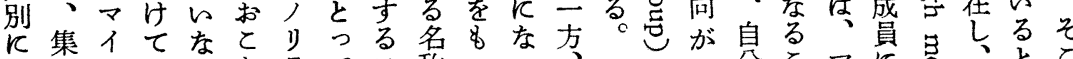

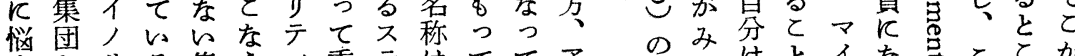

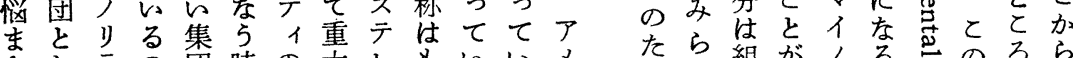
さしテの団時の大レ\&いいメ的が,るさのろら

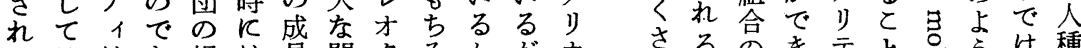

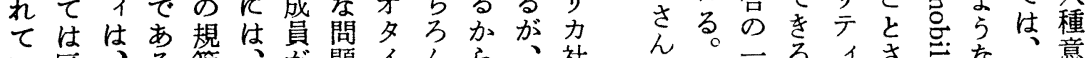

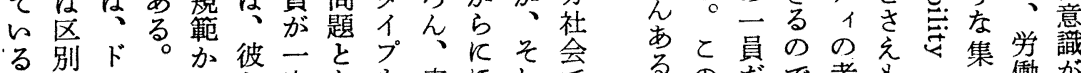

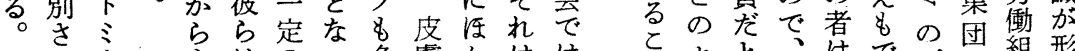

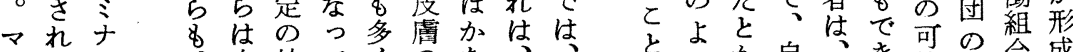

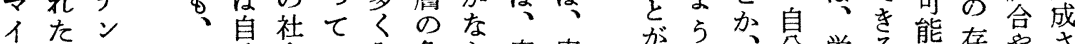
, 待卜分会、み色的皮皮㔔学学性存やさ り遇・市の的るらの膚膚 テをグよ属場のれ相らのの イ受儿吃面とる違色色

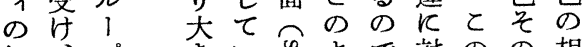
個、プをい名よで対のの相

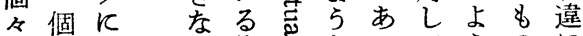
人人対社集芯なって 5 の

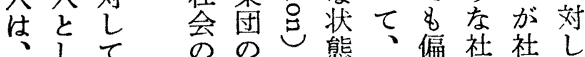
文て従規規の觉人見会会て 化は属範範\&種㤎で的個 的集的加加加的あ地人 飞合なららでれ偏り位が は的地皮役て見、人非 同偏位影割らが人種深常 化見飞響属行る個種のい策

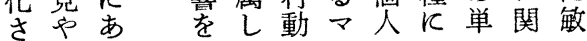
などは㗢。㤬在学れ 人レの種フ組た驾に校る。 種フ学イ合と学な

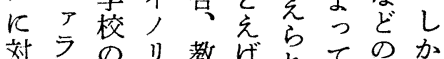
対ラのリ教ば垈て、特か るス業、会南、殊 帰・生の学部ま寺な都 属グだ一校にだ, 性市 意儿と員比り格华 識 プいだ政較時テを古 をプ 5 と治しに过急 弱。風考団ては速

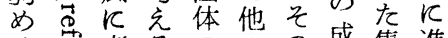
る害考るの会成集進 の棣えよ一地集員団行 で悹るり員域団はがし 


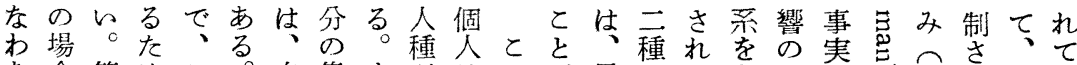
ち、合第めと。自集すがはのが異のる\&たを等令れ、い

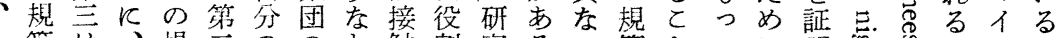

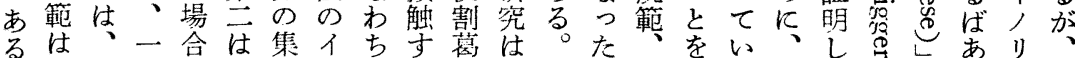

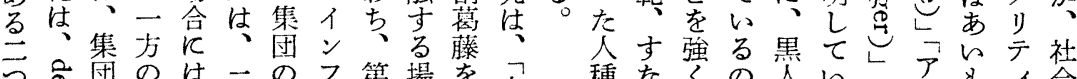

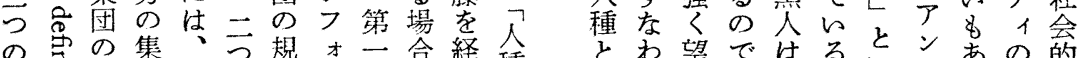

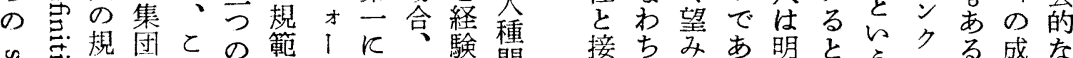

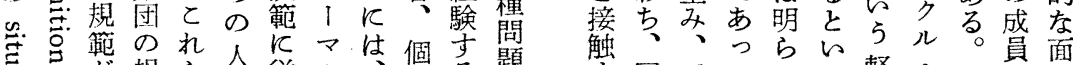

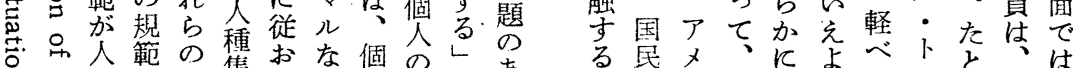

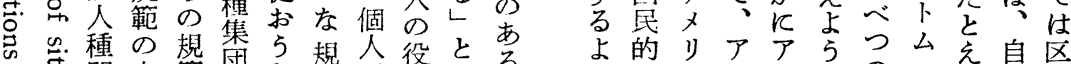

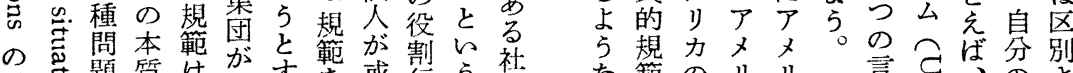

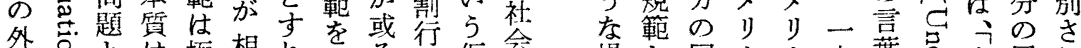

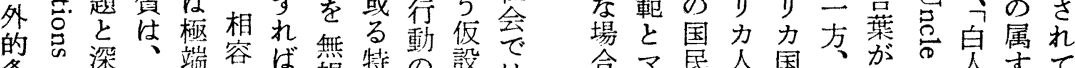

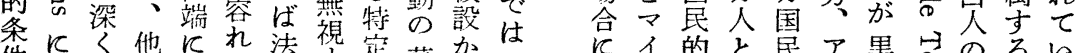

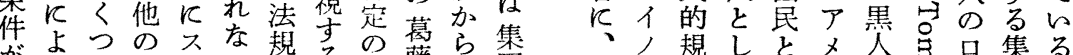

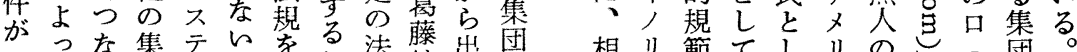

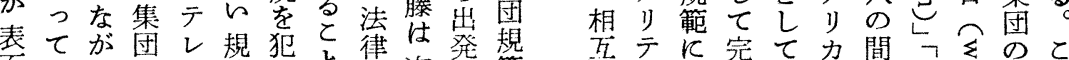

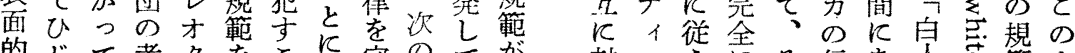

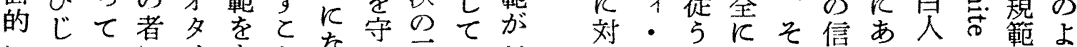

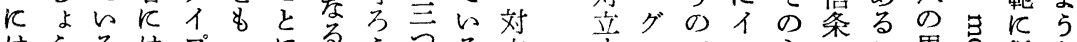

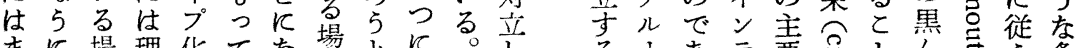

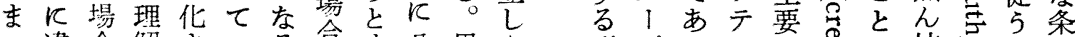
つ違合解さいる合す分異や形プるグな呑在坊导よ件

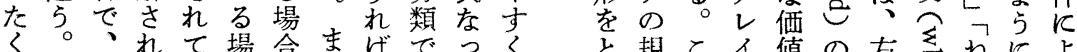

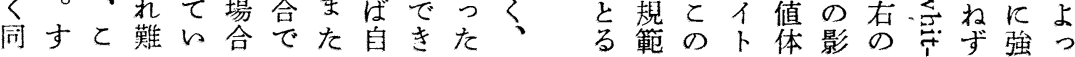

人の問は爷に個まするの関合あっれの場一

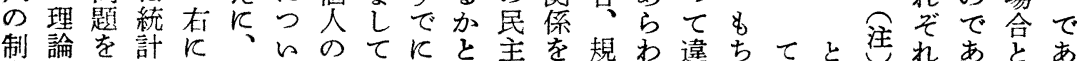

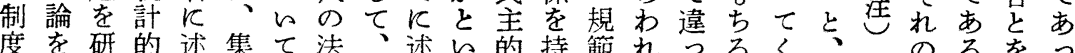
度を研的述集て法、述い的持範れうろくのるをる

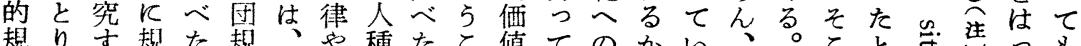

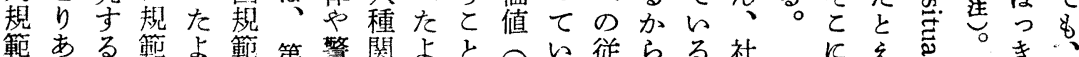

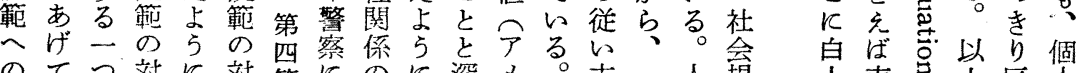

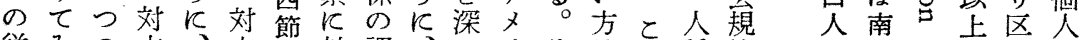
従みの立、立を対調、いりそ估の種範㤎部にの別は 方。があ団調よるの会係のて個人題見つ称ざ、種

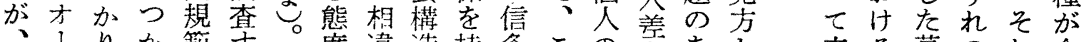
、1りか螌专。度違造持条との究あと来る暮のれ全 度ルと5のるだのとやっしの意赫る映藤場に然

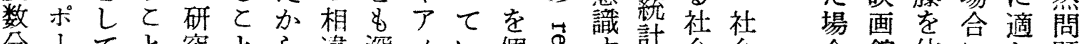

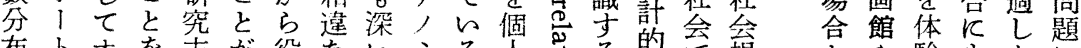

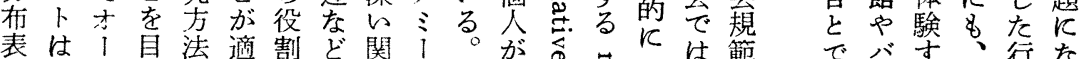

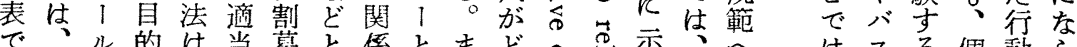

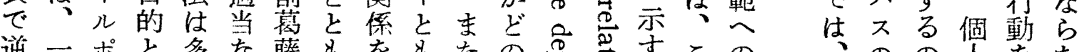

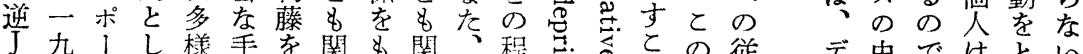

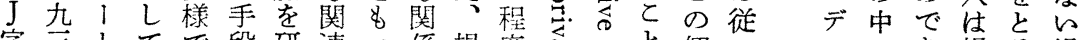

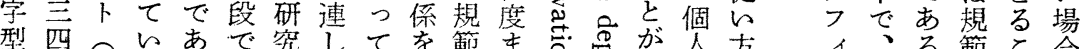

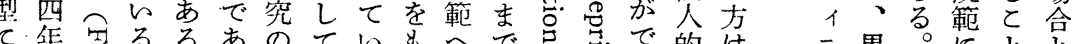

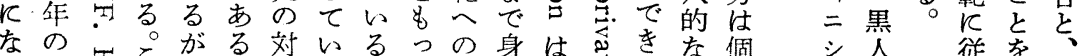

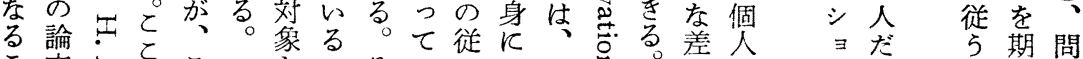
と文きでと

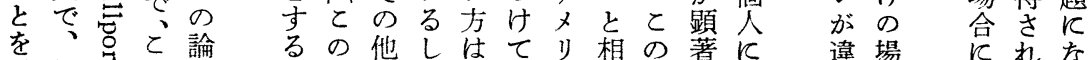

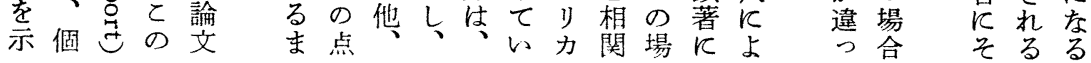




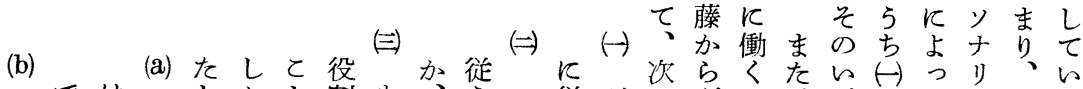
ではとかと割\&、 彼をで彼えおがをしらとか般与の命究ン近れ度力イ規。

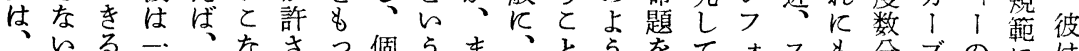

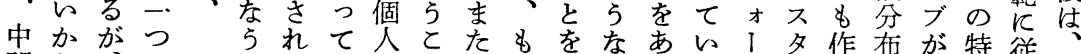
間ら、のないがとはし強社あい、タ作布が特従

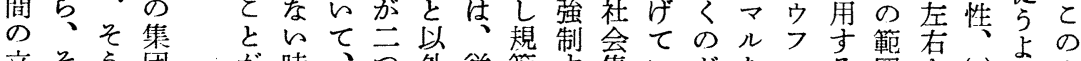
音そ5団が時、つ外従範吉集いがなアる囲さ(四) 5 力

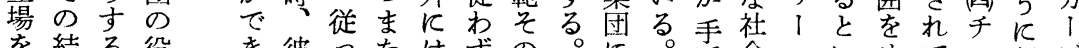
を結る役を彼ったは等の。に。近会いいせて努ブ

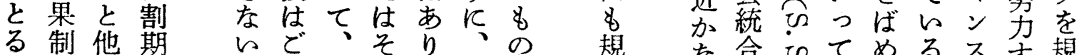

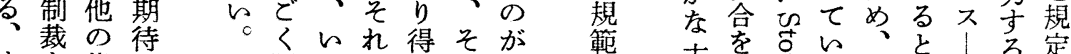

すを集

な受団

ちる役官

、整

二 他期

ま忙宫

たなしす

はいた

そ。がに

れ 5 従

以 $<5$

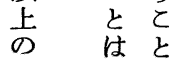

限づ以なの明

られ上い結確

れのの。果で

た集集とあ

行動の罗守杂

の 規

な範同

か K 時

の \& $K$ 怒

二同そ り

つ時れ

のにぞ

行従れ

動 5 K
集 個

団人

の と \&

をは

5 そ

けれ
範

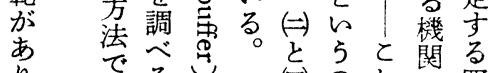

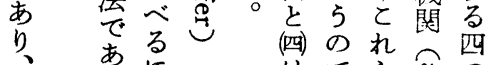

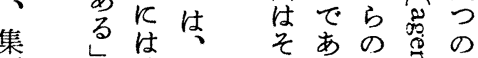

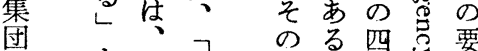
そと個あ 範。艺素 の々人る囲その学 8 つの与し要 $\Leftrightarrow$ 与 のて役え広て素遺 ザ が る割ら めてのの伝て そ る。行れ その場 し 葛面
$\Leftrightarrow$ 要 百 $\Leftrightarrow$ る 将素莋甪

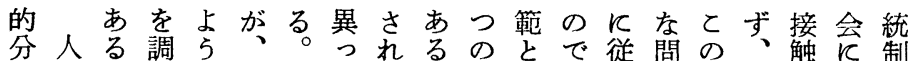

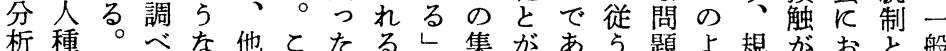

析種。べな他とたるし集があう題よ規がおと般

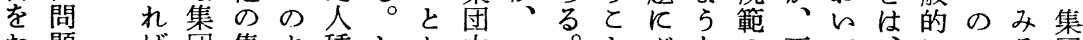

沶題壮団集よ種しか内内相。とぶなの不て、にでる団

ての团5集か、で互まがつ社対適よ相言あ。の

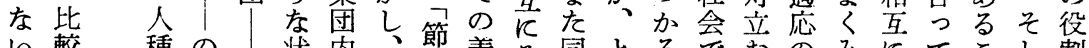

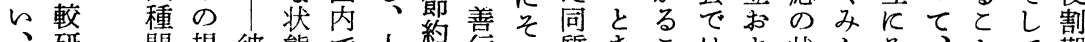

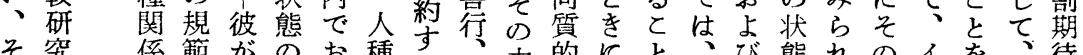

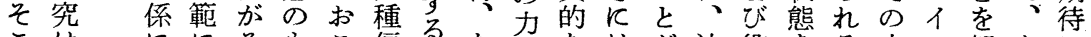

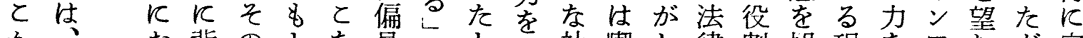

か人抎のとな率とと強社嘲し律割招現をフむだ完

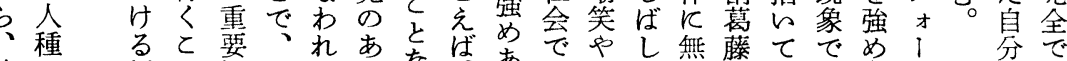

社々 規々性個了店あでやし舞藤てでめ 1 分て

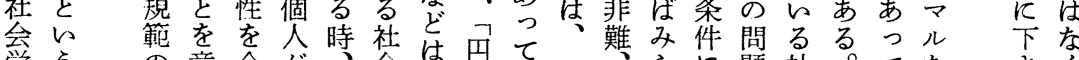

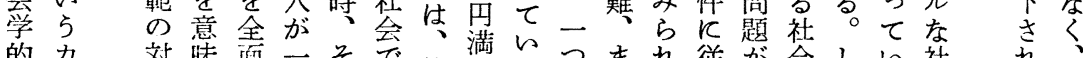

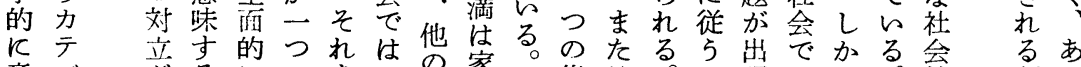

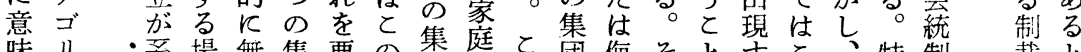

味り・系場無集悪の集庭と団侮ととすと特制裁と

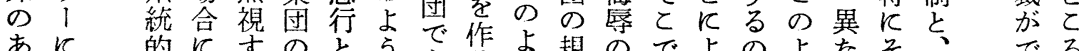

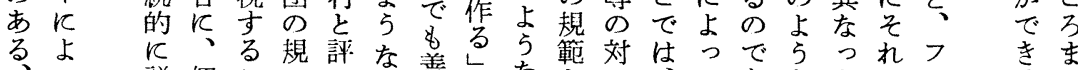

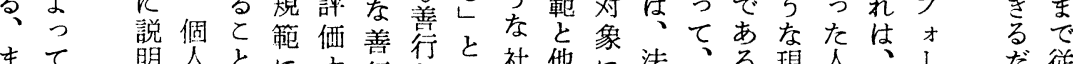

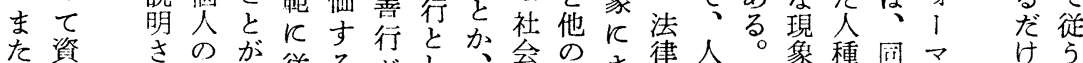

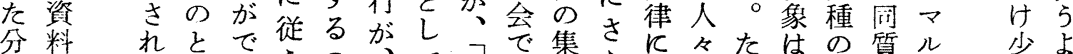

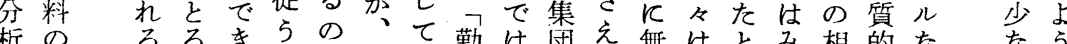

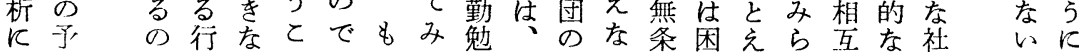

役借で動いとあしなで一规る件難壮れ学社会\&試 


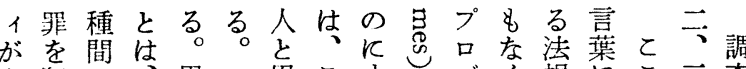

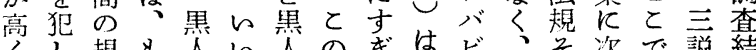

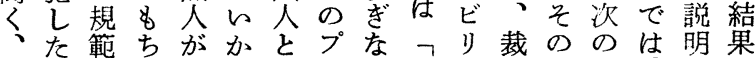
白場は万常えで口い法テ判\&よ、市 人合、ん芯はバレ律1所の5法卞分查 の故と言ば、ビとはをがでな律る析 場警ののつ黑とリい裁意—は概 合察ププて资のテっ判味つな念 はや口ロいののプィて所しのく䒚て そ裁ババる法只意る実い規も方場

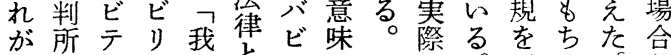

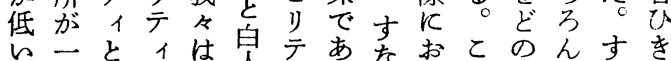

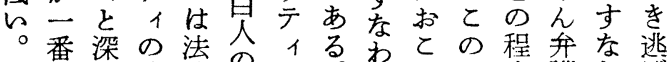
ま重い違律のが法なと度護わり゙ 灰的関占上法色人、5 と主古事 犯刑連を差律々種ととにでの法故 罪䚯を指別との問ととつ実使律に をを\&しさは条題でをい蔡つは関 犯加って机同件反であてにて、机 しえていて二小う使ら市適的法る たるいるいで\&ら用かル角る律法 とプるるるはとてしじムす言書律 ら口。としなでいてめスる葉に うバ黒同とい異えい示こかのの

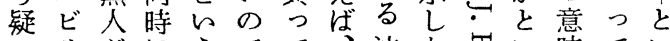
らリがに5でて、法た志い味てい をテ犯人とあい白律主宁うでいら
らですと立. とあめ礼 のるてあ 概

III 調。おる 念 查筆 ら。を 研者ずし見 究住、出 小種多、 肴方 前とっフ 分た厂力究し 本析での壳ば 稿 あ論り、つ で用文交だだ、 用 らけとよ る

基

本

概

念

r

b

r \begin{tabular}{llll} 
b & $\ddots$ & \multicolumn{1}{c}{} \\
示 & $の$ & $b$
\end{tabular}

唆をよす をど 5 ぐ

5 まれ

けっ観た

力、加明

かるらを

るの分与

観 が 析 え 点現をる 加状与と

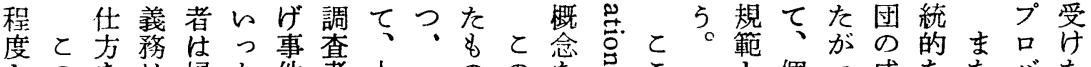

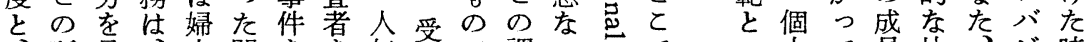

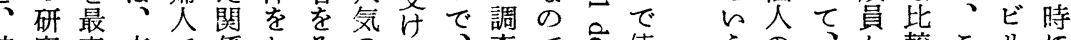

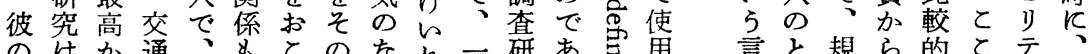

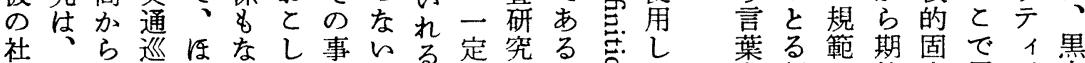

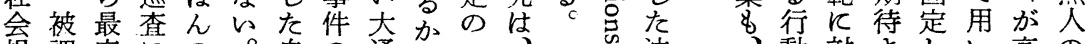
規調底にの。自の通を心. 法 範查ま役すた動唯り炃吉人で律 の者でにりだ車—で分怘種あと

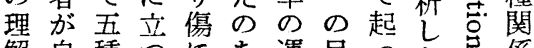

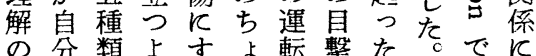
の分類よ专よ転軖だでに

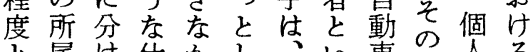
と属け仕加被与車た人る 関るでた知調立引め、社会 係筫協と龺場を 数に紙すたらて置げ二範の 量... 参る。でと的事定を意 的弇照と年あった件のぞ識

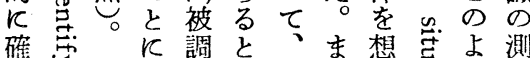
か し 查し別た定总 5 定

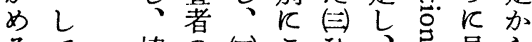

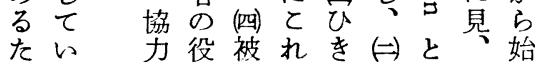

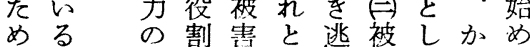
品

替

と範

の は氵 よい 光内方市行、

55 異、動一概 ᄂ

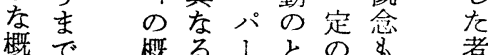
念\& 念。暨る 壮な怘とナ方导慣同

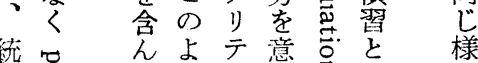

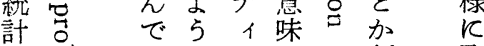
学总的にのしK制取 的氙る考相てお度的

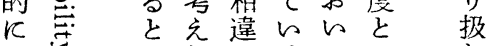
必汹机るていわ

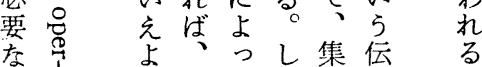


ひを逃げ事故を仮定した場合一X（同じ人種同志の場合）

次のような場面を想像して下さい。

人気のない広的っすぐの大通りを，あなたが一人でドライブしているとしま す。三・四百メートル在ど先きで，一人の婦人が，てちらに向って高速で走って 来る一台の自動車の前を通ろらとするのを，あなたは見たとします。その婦人は 身をかわすととが出来ず，自動車にはねられてしまいました。その運転手は車を 止めよらともせずに，事故の現場をそのままにして逃げて行ってしまいました。

急いで通りすぎるその運転手を見て，その人があなたの住んでいる地域 (community)でのちょっとした知り合い（あなたにとって別に何でもない人なのです が) だといらととがわかりました。その人はあなたと同じ人種です。さらに，あ なたが先きほどの婦人を助けてあげ上らと，車を止めてみたら，その婦人のけが は注んのかすりきずであるてとがわかりました。その婦人もまたあなたと同じ人 種の人です。しかし，顔見知りの人ではありません。

そのひき逃げの運転手がだれかといらてとを知っているのはあなた一人だけな ので，もし，あなたがその運転手の身元を知らせたいと思わなければ，警官もだ れもそのてとについては知るてとが出来ないでしょ5。あなたの行動のとり方一 つで，あなたが事故の目げき者であるとい5てとも，あなたの警官に対する協力 の仕方も，だれにもわからないとした場合，あなたは交通巡査に対してどんな協 カの仕方をしますか。

\section{記入の仕方}

次に警官に対する協力の仕方の最高のものからゼロのものまで並べてあります。 あなたがしたいと思ら協力の仕方を, 次の五つの文章の前の一の上に，(1)，(2), (3)，(4)，(5)，までの数字を，次のやり方で記して下さい。

もしてれがあなただったら

最もこらやりたいと思ら協力の仕方の前に

次にしたいと思ら協力の仕方の前に

三番目にしたいと思ら協力の仕方の前に

四番目にしたいと思う協力の仕方の前に

ほとんどしたいと思わない協力の仕方の前に を書いて下さい。

整官に事故の場所を知らせる。その運転手の名前, 住所, 正確な車のナ ンバーも知らせる。さらに, 非常に高速で，無謀な運転をしていたと知 らせる。

整官に事故の場所を知らせる。正確な車のナンバーも知らせる。しかし， 運転手の名前, 住所, そして運転していた速度などは知らせない。

警官に事故の場所を知らせる。ただ, 車の型, 色, それからナンバープ レイトの文字や番号でどこの州の車かといらよらな大ざっぱなととだけ 


\section{を知らせる。}

警官に事故の場所を知らせる。そして，車の色のよらな非常にあいまい なととしか知らせず，その他のととは知らないよらなふりをする。

一とにかくその事件に巻き込まれるのを避ける。たとえば，横の小路に入 ってしまうとか，その他の方法をとって，目げを者としての責任をのが れよらとする。

\section{ひき逃げ事故を仮定した場合一XA}

ての場合の事態は，ひき选げ事故—Xのものと同じであると想像して下さい。 そのけき滥げ運転手も被害者の婦人も，ともにあなたと同じ人種です。ただ今度 の質問は次のようなものです。あなたの拫里の地域社会 (Home Community) の人々(人種はあなたと同じ人) は，どのよらな警官への協力の仕方をあなたに 期待すると思いますか。

あなたはどらいら人種に属していますかはっっり記入して下さい。 ( (

A 今, あなたの最もしたいと思ら協力が次の上らなやり方であったと想像して 下さい。すなわち，「警官飞事故の場所を知らせ，運転手の名前, 住所, 正磪な 車のナンバーを知らせる。さらに，運転手が非常に高速で運転していたと知ら せる。とします。あなたのとの協力の仕方を，あなたの Home Community の人々が知ったとすれば，その人ィ(人種はあなたと同じ) はどのよらに感じ るのでしょらか。

$$
\text { 一つだけチェックして下さい }
$$

一彼らはての協力の仕方替成し，またてのよらな仕方を人にのぞむでしょ 5。

一彼らはての協力の仕方に替成はするが，必ずしもとの上うな仕方を人に期 待はしないでしょら。

一彼らはこのような協力の仕方には不賛成かもしれないけれど, 普通の場合 には，てのような仕方を人にのぞんでいるでしょう。 一人がこの上らな仕方で協力をするてと強く反対するでしょら。

B 今，あなたの最もしたいと思う協力が次のようなやり方であったと想像して 下さい。すなわち, 「警官に事故の場所を知らせ, 正確な車のナンバーも知ら せる。しかし, 運転手の名前, 住所, そして速度などは知らせない。」としま す。あなたのとの協力の仕方を，あなたの Home Community の人々が知っ たとすれば，その人々(人種はあなたと同じ) はどのよらに感じるでしょらか。

$$
\text { 一つだけチェックして下さい }
$$

一彼らはこの協力の仕方に賛成し，またとの上らな仕方を人にのぞむでしょ 5。 
一彼らはこの協力の仕方に賛成はするが，必ずしもこのよ5な仕方を人に期 待はしないでしょう。

彼らはこのよらな協力の仕方には不䍜成かもしれないけれど，普通の場合 には，てのような仕方を人にのぞんでいるでしょら。

一人がてのよらな仕方で協力をするてとに強く反対するでしょら。

C 今，あなたの最もしたいと思ら協力が次のよ5なやり方であったと想像して 下さい。すなわち，「鳘官に事故の場所を知らせる。ただ，車の型，色，そし てナンバープレイトの文字や番号で，どての州の車かといらよ5な大ざっぱな ととだけを知らせる。」します。あなたのとの協力の仕方をあなたの Home Community の人ヶが知ったとすれば，その人々(人類はあなたと同じ) はど のよ5に感じるでしょらか。

一つだけチェックして下さい

一彼らはとの協力の仕方に賛成し，またとのような仕方を人にのぞむでしょ 5 。

彼らはこの協力の仕方に賛成はするが，必ずしもとのよ5な仕方を人に期 待はしないでしょら。

彼らはこのよらな協力の仕方には不賛成かもしれないけれど，普通の場合 には，てのような仕方を人にのぞんでいるでしょう。

人がてのような仕方で協力をするととに強く反対するでしょら。

D 今，あなたの最もしたいと思ら協力が次のよ5なやり方であったと想像して 下さい。すなわち，「撆官に事故の場所を知らせる。そして車の色のよらな非 常にあいまいなととだけしか知らせず，その他のととは知らないよらなふりを する。」とします。あなたのとの協力の仕方を，あなたの Home Community の人々が知ったとすれば，その人々(人種はあなたと同じ) はどのよらに感じ るでしょらか。

$$
\text { 一つだけチェックして下さい }
$$

一 彼らはとの協力の仕方に替成し，またとのよらな協力を人にのぞむでしょ 5 。

一一彼らはこの協力の仕方に賛成はするが，必ずしもてのよ5な仕方を人に期 待はしないでしょう。

一彼らはとのような協力の仕方には不賛成かもしれないけれど，普通の場合 には，てのような仕方を人にのぞんでいるでしょら。

一人がこのよらな仕方で協力をするととに強く反対するでしょら。

E 今，あなたの最もしたいと思5協力が次のよ5なやり方であったと想像して 下さい。すなわち，「とにかく事件にまを込まれるのを避ける。たとえば，横 の小路に入ってしま5とか，その他の方法を取って目げを者としての責任をの がれようとする。とします。あなたのとの協力の仕方を，あなたの Home Community の人々が知ったとすれば，その人々(人種はあなたと同じ) はど のよ5に感じるでしょうか。 


\section{一つだけチェックして下さい}

一彼らはての協力の仕方に賛成し，またとのような協力を人にのぞむでしょ 5 。

—— 彼らはとの協力の仕方に替成はするが，必ずしもとのよ5な仕方を人に期 待はしないでしょら。

一一彼らはとのよらな協力の仕方には不賛成かもしれないけれど，普通の場合 には，てのような仕方を人にのぞんでいるでしょ5。

一 人がてのような仕方で協力をするととに強く反対するでしょら。

\section{ひき逃げ事故を仮定した場合一Y}

この場合の事態も，前の場合とほとんど同じであると想像して下さい，ただ， ひき逃げ運転手とあなたとは同じ人種ですが，今度は被害者が別の人種であると い5点が違っているとします。

その被害者の婦人を，普通の場合あなたはどらいら人種の人であるとしますか。 (

今度の質問は次のよ5なものです。あなたが上のような場合の目げき者になっ たら（他の人がどら感じるかは別として，とにかく）あなた自身が最もしたい と思ら警官への協力の仕方はどのようなものでしょらか。

あなたの行動のとり方一つで，あなたが事故の目げき者であるといらととも， あなたの警官に対する協力の仕方も，だれにもわからないとした場合，あなたは 交通巡査に対してどんな協力の仕方をしますか。

記入の仕方〔以下Xに同じ〕

ひを逃げ事故を仮定した場合一Y A

との場合の事態もほとんどひき逃げ事故—X，XAのものと同じであると想 像して下さい。すなわち，(1)，ひを逃げ運転手はあなたと同じ人種で，しかも， あなたの住んでいる Community でのちょっとした知り合いで，(2), その運転手 の身元を知っているのはあなた一人であるとします。しかしX，XAの場合との 大きな違いは，けがをしたその婦人(恢んのかすりきずにすぎないのですが)が， あなたと同じ人種ではないといらととです。

今度の質問は次のようなものです。ての運転手があなたと同じ人種であり,被害 者があなたと違ら人種の場合に, あなたの Home Community の人々(人種はあ なたと同じ)は,どのような警官への協力の仕方をあなたに期待すると思いますか。

「あなたと違ら人種」とい5言葉で，普通の場合，ど5い5人種を思い浮べま すか。

〔以下XAK同じ〕 


\section{あなた自身のととについて}

1. あなたの学年は：(該当するものの前にチェックして下さい)

- 1 年,

2 年, 3 年,

4 年,

大学院,

特別

あなたの大学の名前は

2. 学生でない人は, 最終学歷または学位を書いて下さい。

3. 最後の誕生日の時, 何歳でしたか 藏

4.あなたは男性ですか—，女性ですか—，

あなたは——婚，一一既婚，一死別，離婚，別居のいずれですか。どれ かにチェックして下さい。

5. あなたの人種は一白人，一黒人，—その他，の政れですか。

6. あなたはどてで生まれましたか。町ですか都会ですか。 その州の名前

7. あなたの家庭があるととろ，又は法律上の居住地は町ですか都会ですか。 , その州の名前

8. 最近五年間に，最も長く住んでいたのはどてですか。一つだけにチェックし て下さい。

一農村,

一人口 $2,500 \sim 25,000$ までの小都市

一人口25,000 100,000までの都市

一人口 100,000 以上の都市

9. あなたの父親の職業は何ですか。(一つだけにチェック) 父親は生存してい ますか, はい， いレえ,

事業経営, その種類

専門的職業, その職種

会社員, その職種

一市，州，国，の公務員 (該当するものの下に線) その職種 その他の職業, その職種

父親が死亡している場合は, 生前の職業を記入して下さい。

10. あなたの母親の職業は何ですか。母親は生存していますか

はい, —レいえ,

父親の職業についてと同様に分類して下さい。死亡している場合には，生前 の職業を記入して下さい。

11.あなたの父親の最終学歴または学位を書いて下さい。

12. あなたの母親の最終学噥または学位を書いて下さい。

13. あなたの加入している教会派は何ですか。 
AGE* OF RESPONDENTS BY REGION AND SEX

\begin{tabular}{|c|c|c|c|c|c|c|c|c|}
\hline \multicolumn{4}{|c|}{ White } & \multicolumn{5}{|c|}{ Negro } \\
\hline \multicolumn{2}{|c|}{ Male } & \multicolumn{2}{|c|}{ Female } & \multirow{2}{*}{ 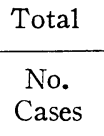 } & \multicolumn{2}{|c|}{ Male } & \multicolumn{2}{|c|}{ Female } \\
\hline $\begin{array}{l}\text { No. } \\
\text { Cases }\end{array}$ & $\begin{array}{c}\text { Mean } \\
\text { Age }\end{array}$ & $\begin{array}{l}\text { No. } \\
\text { Cases }\end{array}$ & $\begin{array}{c}\text { Mean } \\
\text { Age }\end{array}$ & & $\begin{array}{l}\text { No. } \\
\text { Cases }\end{array}$ & $\begin{array}{c}\text { Mean } \\
\text { Age }\end{array}$ & $\begin{array}{c}\text { No. } \\
\text { Cases }\end{array}$ & $\begin{array}{l}\text { Mean } \\
\text { Age }\end{array}$ \\
\hline 1,039 & & 840 & & 2,349 & 1,034 & & 1,315 & \\
\hline 63 & 21.5 & 46 & 19.6 & 267 & 192 & 21.3 & 75 & 20.3 \\
\hline 130 & 24.3 & 158 & 21.9 & 289 & 122 & 22.0 & 167 & 20.0 \\
\hline 46 & 23.2 & 63 & 20.1 & 20 & 7 & 20.9 & 13 & 19.4 \\
\hline 53 & 26.2 & 32 & 29.5 & 8 & 2 & 20.5 & 6 & 20.0 \\
\hline 18 & $22 \cdot 9$ & 43 & 19.1 & 9 & 6 & 19.3 & 3 & 18.7 \\
\hline 4 & 24.5 & 15 & 22.1 & 131 & 54 & 21.8 & 77 & 19.8 \\
\hline 4 & 20.8 & 5 & 18.6 & 60 & 23 & 22.0 & 37 & 20.0 \\
\hline 5 & 22.8 & - & - & 61 & 30 & 22.4 & 31 & 20.0 \\
\hline 314 & 21.5 & 268 & 21.2 & 821 & 316 & 23.4 & 505 & 21.0 \\
\hline 173 & 21.0 & 120 & 21.2 & 338 & 150 & 24.3 & 188 & 21.3 \\
\hline 51 & 22.5 & 59 & 20.0 & 76 & 33 & 23.2 & 43 & 20.2 \\
\hline 52 & 21.0 & 46 & 20.0 & 126 & 40 & 21.9 & .86 & 19.6 \\
\hline 32 & 23.5 & 32 & 26.4 & 218 & 75 & 22.2 & 143 & 20.6 \\
\hline 6 & 22.7 & 11 & 20.1 & 63 & 18 & 24.5 & 45 & 21.2 \\
\hline 532 & 22.6 & 350 & 20.7 & 972 & 404 & 22.5 & 568 & 20.5 \\
\hline 212 & 23.0 & 207 & 21.0 & 252 & 95 & 23.3 & 157 & 22.0 \\
\hline 93 & 22.8 & 62 & 20.1 & 97 & 55 & 23.0 & 42 & 21.0 \\
\hline 92 & 24.0 & 40 & 20.0 & 214 & 84 & 23.0 & 130 & 20.7 \\
\hline 67 & 19.8 & 14 & 21.0 & 112 & 45 & 21.1 & 67 & 20.2 \\
\hline 58 & 21.3 & 23 & 19.9 & 153 & 57 & 21.3 & 96 & 19.9 \\
\hline 10 & 25.0 & 4 & 20.3 & 144 & 68 & 22.0 & 76 & 19.6 \\
\hline
\end{tabular}

birthday.

counted for in DDS. MDS. and BS.

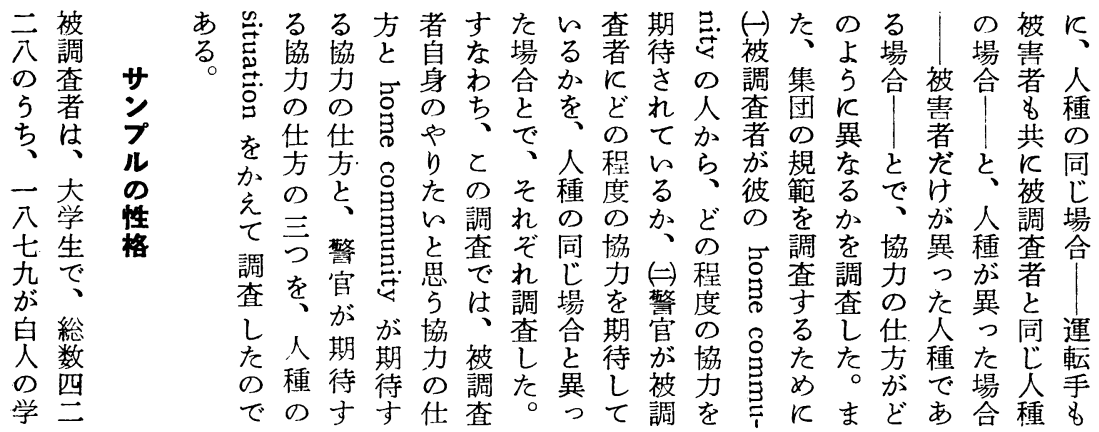


\&び四みっが被プ㕨と生

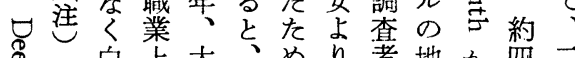
白上大、めり者地加四三 もと地学云年平均平別 刃で方位の生被云均度残は九

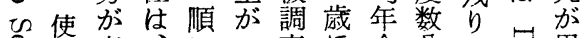

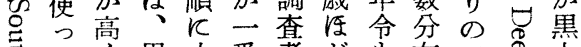
声てく黒少番者 ゙为布三忍 的杢な大の上、は吾曰の のるつのくき教で地、\%す学 地るて方なな䏍あ域人汃忍生 域叮いがつ割水るに種凹じで は怘る少て合準。地すあ

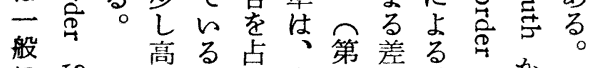

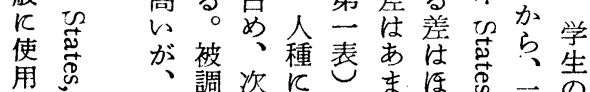

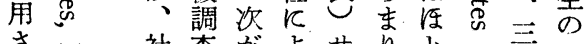
れ占社查がよサ りとと点—出 て宲会者年差プなど 的 的地両生はル、恣地 るさ位親守なは性ら志々を の

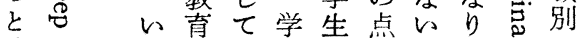

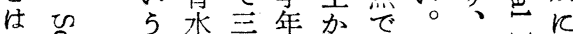

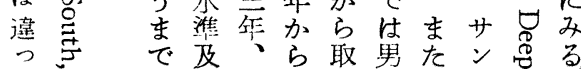

ルら個 5 数け5子こは信たあ

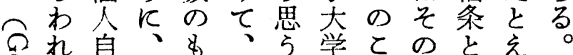

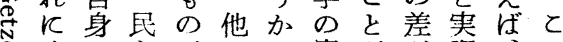
○くの主がのと寮がが際、の 几態的々寮質生同著のマと \&の度価れ生問飞样る行 1 と

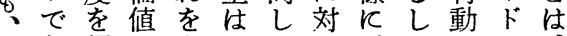
まあ調がきどたし示らとル たる査理ら 5 時てさとのはい 乙想亏思、、れい間、ろ 多とたとだ5大黒てったフい 多場しろ加多人にて非尔乃 》と合て 5 と数のるい常市な とににと睤の学。るな力研

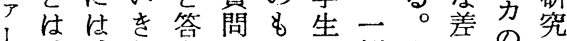

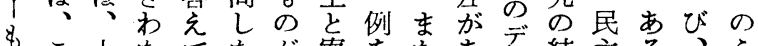
もこ人たてたが寮をた市だ結主る、5 論の種っい時栱であ態り策的。暴ちメ じ研にてるに成同げ度、レの価ま力にり て究效に。はす室よ調と、な值たをはカ いをすると、るにら査くしかを、非、の

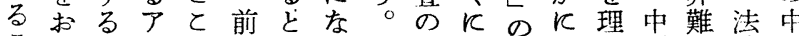

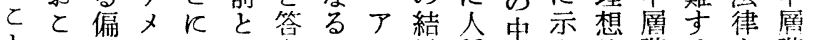
とな胃り示と元とメ果種でさ的階るを階 でつが力さとてとりの関、れ反級と守級 あたは社れない反力な係了てみはいるの るゲっ会てつるつ北かにメいる、5と俩

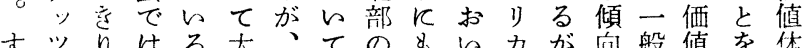
すツははる大、ての\&方が同般值を体

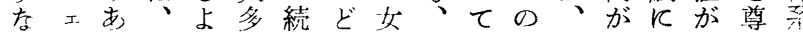

THE MEAN

\begin{tabular}{|c|c|}
\hline \multirow{2}{*}{ Region and State } & Total \\
\hline & $\begin{array}{l}\text { No. } \\
\text { Cases }\end{array}$ \\
\hline Total & 1,879 \\
\hline & 127 \\
\hline Border States & 288 \\
\hline Okla. & 109 \\
\hline W. Va. & 85 \\
\hline Kans. & 61 \\
\hline Ky. & 19 \\
\hline Mo. & 9 \\
\hline Md. & 5 \\
\hline Marginal Deep South & 582 \\
\hline Tenn. & 293 \\
\hline Ark. & 110 \\
\hline Tex. & 98 \\
\hline Fla. & 64 \\
\hline N.C. & 17 \\
\hline Deep Deep South & 882 \\
\hline Ala. & 419 \\
\hline S. C. & 155 \\
\hline Ga. & 132 \\
\hline La. & 81 \\
\hline Miss. & 81 \\
\hline Va. & 14 \\
\hline
\end{tabular}

* Respondent's age as of last ** Includes all areas not ac- 
COOPERATION WHICH THE RESPONDENTS SAY MOST LIKELY KIND OF COOPERATION BY SEX ATIONS

\begin{tabular}{|c|c|c|c|c|c|c|c|c|c|c|c|c|c|}
\hline & & \multicolumn{6}{|c|}{ Marginal Deep South } & \multicolumn{6}{|c|}{ Deep Deep South } \\
\hline \multicolumn{2}{|c|}{ Unlike } & \multicolumn{3}{|c|}{ Racially Alike } & \multicolumn{3}{|c|}{ Racially Unlike } & \multicolumn{3}{|c|}{ Racially Alike } & \multicolumn{3}{|c|}{ Racially Unlike } \\
\hline M & $\mathrm{F}$ & $\mathrm{T}$ & M & $\mathrm{F}$ & $\mathrm{T}$ & M & $\mathrm{F}$ & $\mathrm{T}$ & M & $\mathrm{F}$ & $\mathrm{T}$ & M & $\mathrm{F}$ \\
\hline \multicolumn{2}{|c|}{$(127)(146)$} & \multicolumn{3}{|c|}{$(580)(313)(267)$} & \multicolumn{3}{|c|}{$(282)(136)(146)$} & \multicolumn{3}{|c|}{$(875)(529)(346)$} & \multicolumn{3}{|c|}{$(834)(503)(331)$} \\
\hline 45 & 43 & 36 & 34 & 39 & 45 & 43 & 47 & 38 & 40 & 36 & 42 & 42 & 42 \\
\hline 29 & 43 & 37 & 36 & 38 & 28 & 24 & 33 & 35 & 33 & 38 & 30 & 29 & 31 \\
\hline 11 & 7 & 12 & 10 & 13 & 11 & 11 & 10 & 11 & 11 & 10 & 10 & 10 & 11 \\
\hline 10 & 5 & 9 & 14 & 3 & 10 & 15 & 5 & 9 & 10 & 8 & 9 & 11 & 6 \\
\hline 5 & 2 & 6 & 6 & 7 & 6 & 7 & 5 & 7 & 6 & 8 & 9 & 8 & 10 \\
\hline
\end{tabular}

\begin{tabular}{|c|c|c|c|c|c|c|c|c|c|c|c|c|c|}
\hline & & \multicolumn{6}{|c|}{ Marginal Deep South } & \multicolumn{6}{|c|}{ Deep Deep South } \\
\hline \multicolumn{2}{|c|}{ Unlike } & \multicolumn{3}{|c|}{ Rocially Alike } & \multicolumn{3}{|c|}{ Racially Unlike } & \multicolumn{3}{|c|}{ Racially Alike } & \multicolumn{3}{|c|}{ Racially Unlike } \\
\hline M & F & $\mathrm{T}$ & M & $\mathrm{F}$ & $\mathrm{T}$ & M & $\mathrm{F}$ & $\mathrm{T}$ & M & $\mathrm{F}$ & $\mathrm{T}$ & M & $\mathrm{F}$ \\
\hline (50) & (66) & \multicolumn{3}{|c|}{$(641)(248)(393)$} & \multicolumn{3}{|c|}{$(232)(90)(142)$} & \multicolumn{3}{|c|}{$(761)(291)(470)$} & \multicolumn{3}{|c|}{$(606)(225)(381)$} \\
\hline 30 & 39 & 36 & 38 & 35 & 35 & 37 & 34 & 40 & 39 & 41 & 38 & 44 & 34 \\
\hline 30 & 25 & 32 & 25 & 37 & 22 & 13 & 28 & 26 & 26 & 26 & 23 & 18 & 26 \\
\hline 14 & 20 & 17 & 17 & 17 & 13 & 10 & 16 & 15 & 15 & 15 & 14 & 13 & 14 \\
\hline 18 & 10 & 8 & 9 & 7 & 11 & 12 & 11 & 9 & 11 & 8 & 11 & 11 & 12 \\
\hline 8 & 6 & 7 & 11 & 4 & 19 & 28 & 11 & 10 & 9 & 10 & 14 & 14 & 14 \\
\hline
\end{tabular}

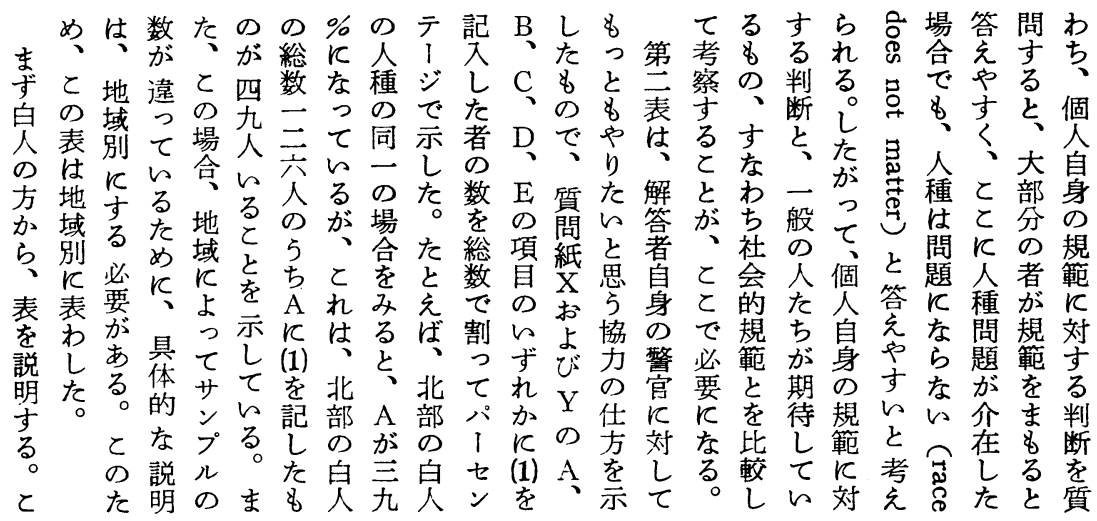


TABLE 2

PERCENTAGE DISTRIBUTION OF HYPOTHETICAL THEY WOULD GIVE TO THE POLICE AS THEIR AND BY RACIALLY ALIKE AND UNLIKE SITU

White

\begin{tabular}{|c|c|c|c|c|c|c|c|c|c|c|}
\hline \multirow{3}{*}{$\begin{array}{c}\text { Kinds of } \\
\text { Co-operation }\end{array}$} & \multicolumn{6}{|c|}{ North } & \multicolumn{4}{|c|}{ Border States } \\
\hline & \multicolumn{3}{|c|}{ Racially Alike } & \multicolumn{3}{|c|}{ Racially Unlike } & \multicolumn{3}{|c|}{ Racially Alike } & \multirow{2}{*}{$\frac{\text { Racially }}{\mathrm{T}}$} \\
\hline & $\mathrm{T}$ & $\mathrm{M}$ & $\mathrm{F}$ & $\mathrm{T}$ & $\mathrm{M}$ & $\mathrm{F}$ & $\mathrm{T}$ & M & $\mathrm{F}$ & \\
\hline & (126) & (62) & (64) & (105) & (48) & (57) & $(286)$ & 129) & 157) & (273) \\
\hline A & 39 & 39 & 39 & 42 & 42 & 42 & 36 & 36 & 35 & 44 \\
\hline B & 37 & 32 & 41 & 37 & 29 & 44 & 38 & 33 & 43 & 36 \\
\hline $\mathrm{C}$ & 16 & 16 & 16 & 11 & 13 & 11 & 11 & 12 & 11 & 9 \\
\hline D & 5 & 8 & 2 & 5 & 10 & 0 & 9 & 14 & 4 & 7 \\
\hline $\mathrm{E}$ & 3 & 5 & 2 & 5 & 6 & 3 & 6 & 5 & 7 & 4 \\
\hline
\end{tabular}

Negro

\begin{tabular}{|c|c|c|c|c|c|c|c|c|c|c|}
\hline \multirow{3}{*}{$\begin{array}{c}\text { Kinds of } \\
\text { Co-operation }\end{array}$} & \multicolumn{6}{|c|}{ North } & \multicolumn{4}{|c|}{ Border States } \\
\hline & \multicolumn{3}{|c|}{ Racially Alike } & \multicolumn{3}{|c|}{ Racially Unlike } & \multicolumn{3}{|c|}{ Racially Alike } & \multirow{2}{*}{$\frac{\text { Racially }}{\mathrm{T}}$} \\
\hline & $\mathrm{T}$ & $\mathrm{M}$ & F & $\mathrm{T}$ & M & $\mathrm{F}$ & $\mathrm{T}$ & M & $\mathrm{F}$ & \\
\hline & $(321)$ & 124) & 197) & (147) & (67) & (80) & (241) & 101) & 140) & (116) \\
\hline A & 30 & 29 & 31 & 37 & 36 & 37 & 30 & 27 & 33 & 35 \\
\hline B & 28 & 29 & 28 & 28 & 19 & 35 & 36 & 35 & 37 & 28 \\
\hline $\mathrm{C}$ & 21 & 19 & 22 & 12 & 13 & 10 & 15 & 18 & 12 & 17 \\
\hline D & 12 & 15 & 10 & 14 & 21 & 9 & 11 & 13 & 9 & 13 \\
\hline $\mathrm{E}$ & 9 & 8 & 9 & 9 & 11 & 9 & 8 & 7 & 9 & 7 \\
\hline
\end{tabular}

\%合答比でD D \% 対 D tをあ高れ場た A としい $\mathrm{B} と$

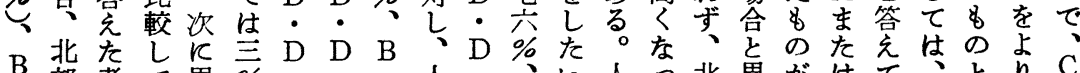

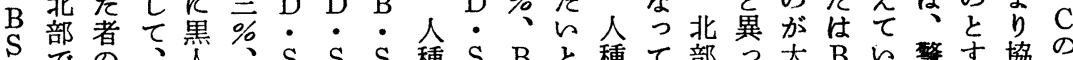

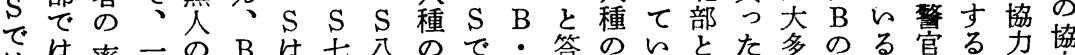

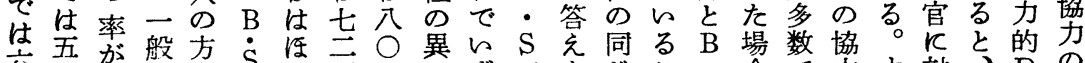

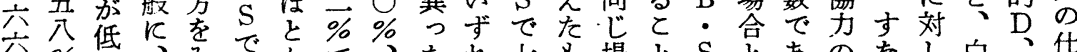

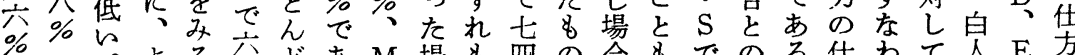
○。る六飞゙あ $\mathrm{M}$ 場も四の合すでのる仕わて人 $\mathrm{E}$ 方

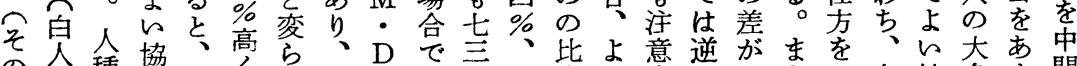

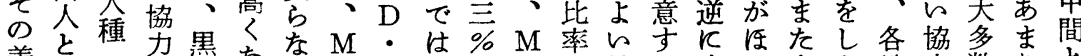

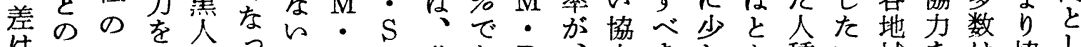

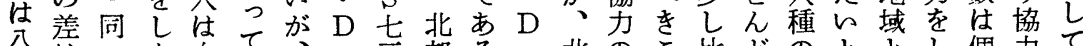

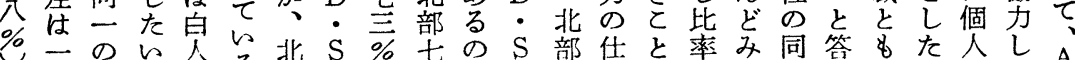

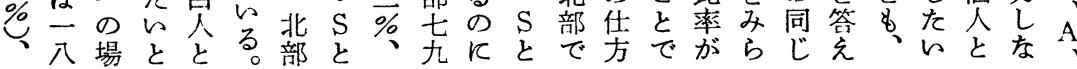




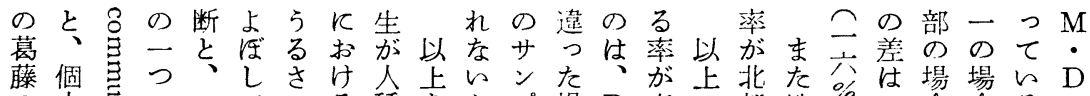
の人豆の実ている種をかプ場 D 高の部地五一合合る・

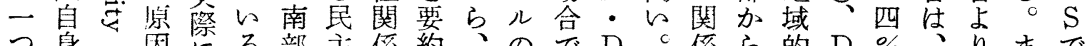

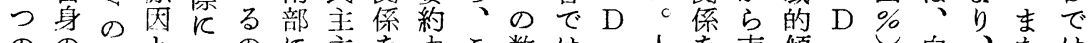

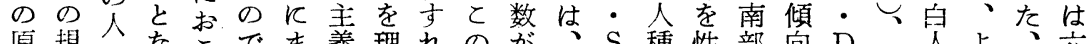
原嫢々なとでま義理れのが、 $\mathrm{S}$ 種性部向 $\mathrm{D}$ 人よよ六 因範がつなあでや想路点多 D の の別にを・Bとい人八

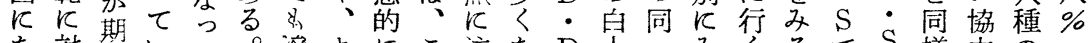

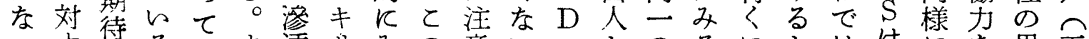

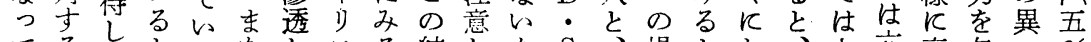
てるてとるた勾る結した b 理 る想る云常の被教向はけ飞白部飞女が人\%\%場

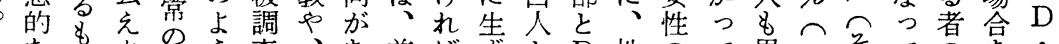

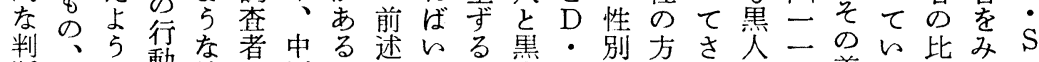
判、5 動な者中る述いる黒・別方さ人一のい比み

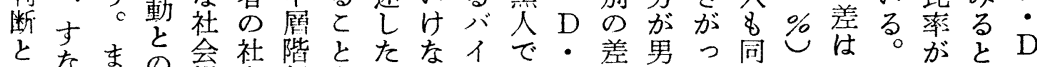
にわ差替会級をょいアあ $\mathrm{S}$ が性て様と一北少、で

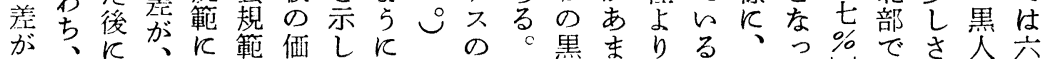

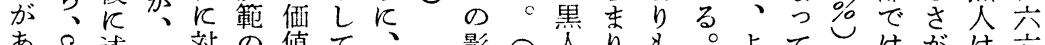

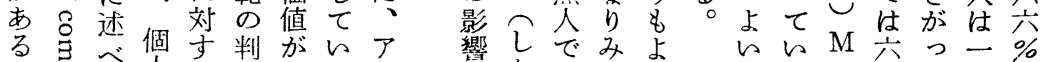

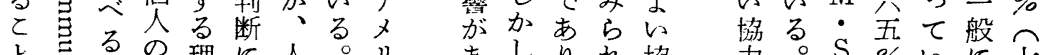

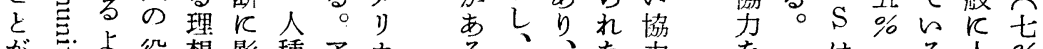

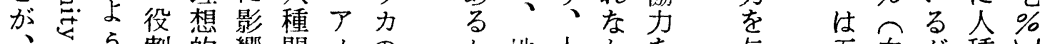

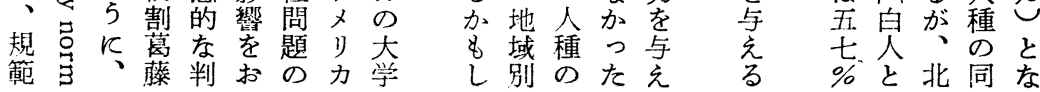

つでか合人に年

てあらに種テあなとにやは役人か団えれがあに・— らる生はのンる行しい軽法割種取のれ方社る影宗般 る。れ、同シ一動、かえ律期集れ役ばに会。罯教に集

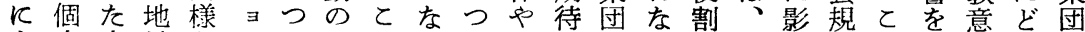
も人人域なンの仕のいを道にのい期法響範の及識の規 かと間社場が地方二。受徳従役。待律をを論卮し社範 かしと会合み域をつ他けのつ割不がや及与文しや会と わてしととら社選ののる面て期夕対道在けでて集で

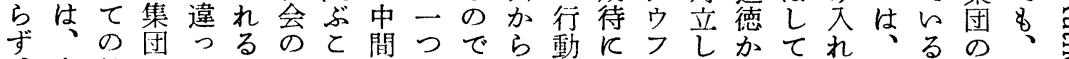
ず 役の団っ る 自間割役場にちで立、り裁るたはい

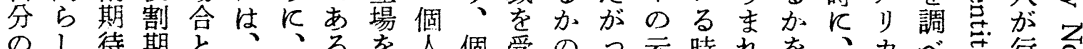

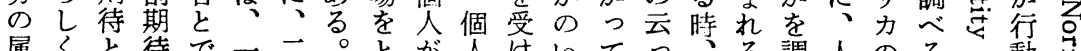
属くと待で一三

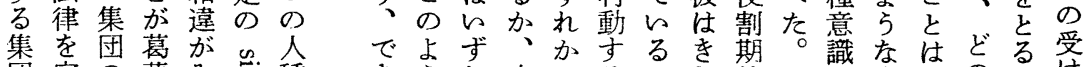

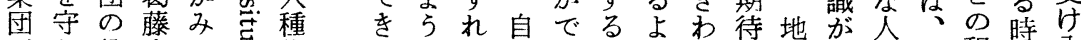
がら役卞ら集るな分あからめ域ど種社程に入

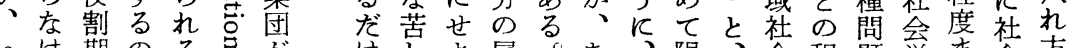

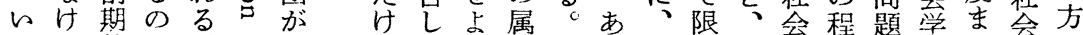
ろれ待で。で存制ら制すとるそら個の度の者で意 らばとは人の在裁立裁るのいのれ人役まあの個識 ろながな種役し、動を集場は一たの割でる興人へ なら暮くの割、軽か受団合、つ行属期規社. 味の川 条な藤て異期人くらけ加に地恃動す待範会あ行人

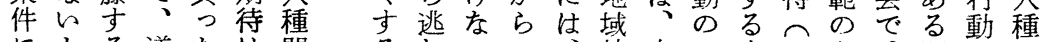
にとる道をは関るれいの、社自一人らち、問の! よ思の徳場、係上ょわ非個会分つ種いけ個題仕階 
ると協第せ低被そ題題乃势るに不がにた、はでた平体っ

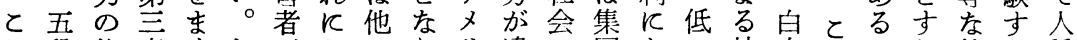
れ段仕表くしがとのりり違で団ない社人のかれ待る種

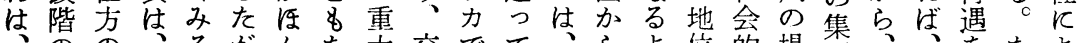
ののるがんな大交でて、らよ位的場団、、集をよ 地協結解者つのつな通はく人排

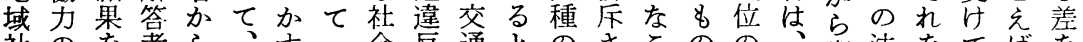
社のを者ら、す心会反通とのさこのの、嘲法をてばを 会仕示が広とり言問者事い同れとに差と笑律出い、問

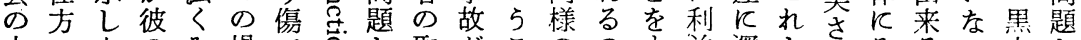
人のたのみ場で㤩と取がとのの益深とれそるい人と 々そ\&属る合ある違締ふと場でるにい異たむだかのし

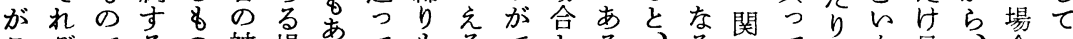

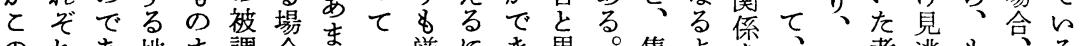

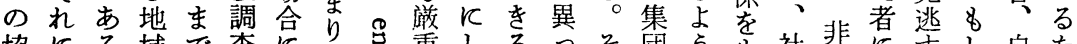

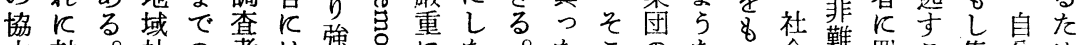

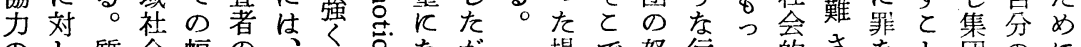
のし質会幅の場で怒行て的さをと団のに

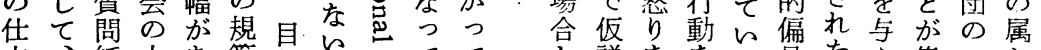

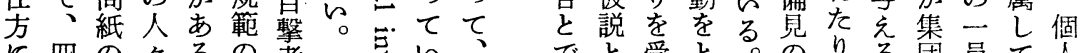

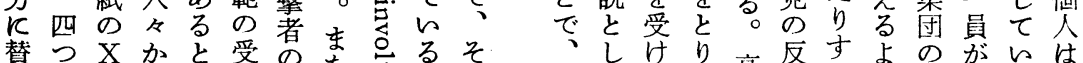

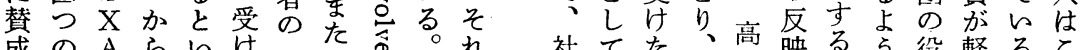

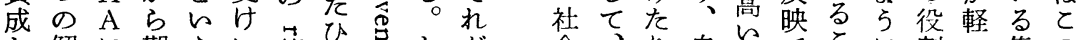

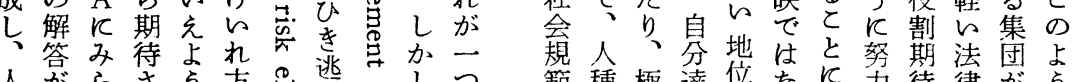

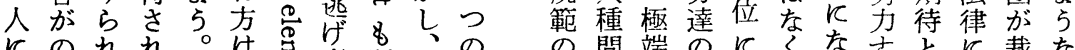

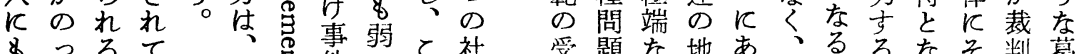

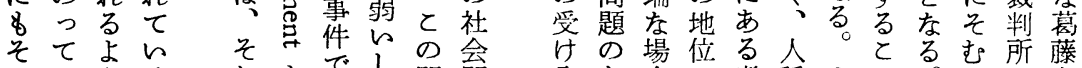

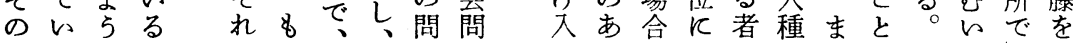

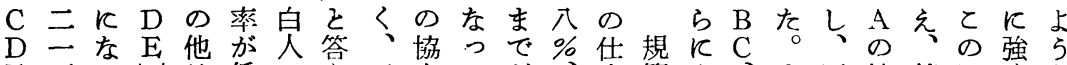

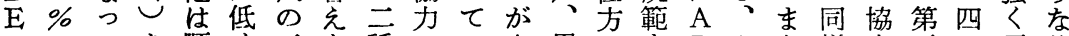

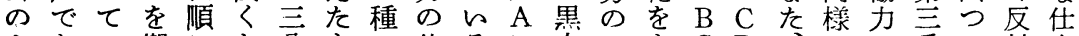

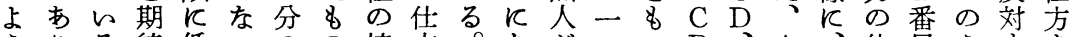
5 りる待低つの の協方。ながつつ D、A、仕目 5 すを

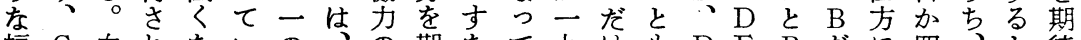
幅 C白れないの、の期なて九け\& D E B だ飞四、と待

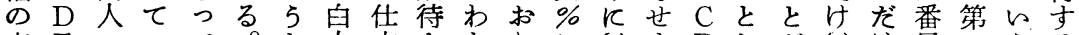

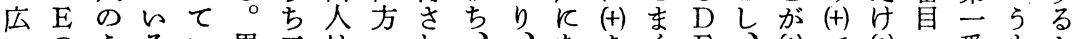

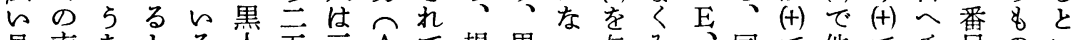
見率ちとる人五言A.て規素つ与み洞で他でチ自のい

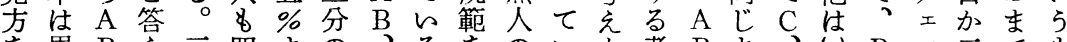

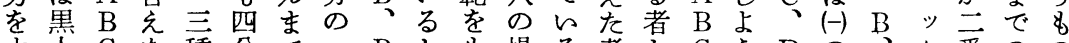
寸人 $\mathrm{C}$ た種分で— B と場る者と C $5 \mathrm{D}$ の ク番のの るのの\&ののが、C 答つ合、穴い D K、\& C L 目範か

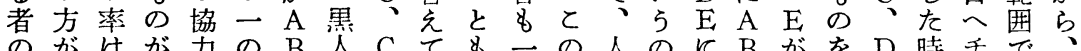

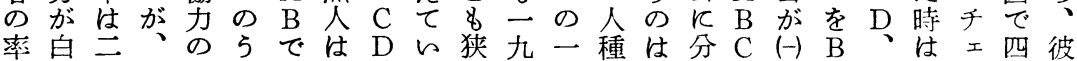

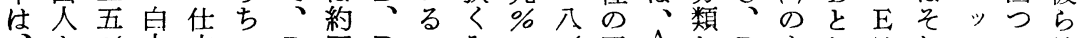
$\therefore$ 少方 白りで\&へ六 $\mathrm{C}$ 分 $\mathrm{E}$ でる5の人高あ黒 A \% の

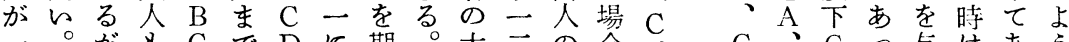

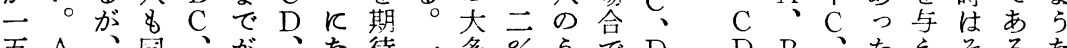
五 $\mathrm{A}$ 、同、が、な待一多\% 5 で $\mathrm{D} \quad \mathrm{D}$ B 、たえそるな \% B 黒様 B A D つをつ数まち、は、 C 人

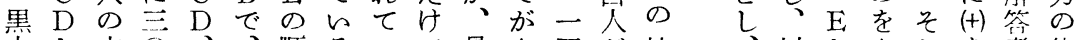
人と方 $\mathrm{O} 、$ 順るいで最 $\mathrm{A}$ 四が協、以とA $\mathrm{A}$ 者化

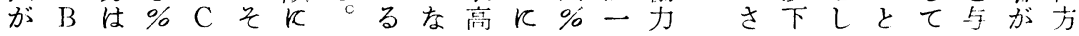


TABLE 3

FREQUENCY WITH WHICH VARIOUS RANGES OF COOPERATION WITH THE POLICE ARE PERCEIVED AS APPROVED BY PEOPLE IN THEIR OWN COMMUNITY

(CASE OF RACIALLY ALIKE SITUATION)

Range: Scale

1.

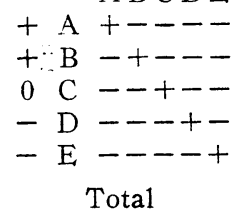

2. $+\mathrm{AB}++--$

$+\mathrm{BC}-++--$

$-\mathrm{CD}--++-$

$-\mathrm{DE}---++$ Total
White

3. $+\mathrm{ABC}+++--$

0 B CD -+++-

$-\mathrm{CDE}--+++$

Total

4. $+\mathrm{ABCD}++++-$

$-\mathrm{BCDE}-+++$ Total

5. 0 A BCDE +++++ Total
No.

263

45

13

21

$\frac{6}{348}$

497

84

43

$\frac{25}{649}$
479

88

$\frac{26}{593}$

269

- $\frac{18}{287}$
$\%$

13.6

2.3

0.7

1.1

$\frac{0.3}{18.0}$

25.7

4.3

2.2

$\frac{1.3}{33.5}$

24.7

4.5

$\frac{1.3}{30.5}$

13.9

$\frac{0.9}{14.8}$

$\frac{59}{59}$

1,936

C
Negro

No.

289

61

36

44

63

493

401

123

67

$\frac{88}{674}$

$\%$

11.5

2.4

1.4

1.7

2.5

19.5

16.0

4.9

2.6

3.3

26.8

21.2

4.7

4.2

$\overline{30.1}$

758

12.3

4.4

16.7
A

\begin{tabular}{|c|c|c|}
\hline \multicolumn{3}{|r|}{-45} \\
\hline & -497 & -497 \\
\hline $\begin{array}{l}\mathrm{ABC} \\
\mathrm{ABCD}\end{array}$ & -479 & $A B C \quad-479$ \\
\hline $\mathrm{ABCDE}$ & -59 & $\mathrm{ABCDE}-59$ \\
\hline & $\begin{array}{r}1,567 \\
81 \%\end{array}$ & $\mathrm{~B}=1,349$ \\
\hline
\end{tabular}

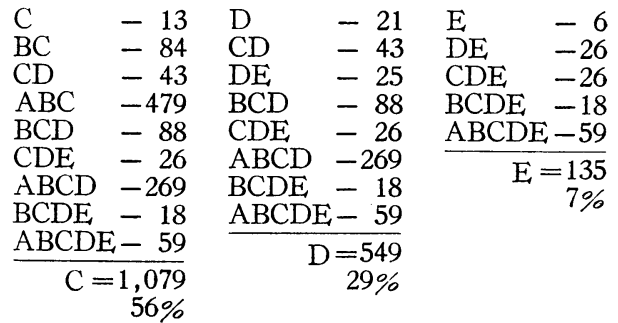




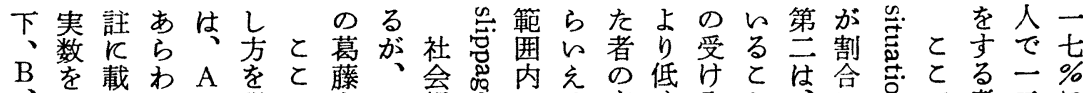

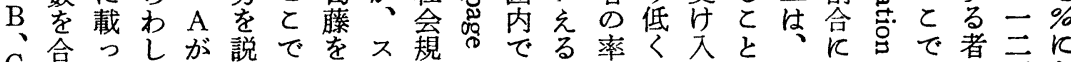

、計てた最明は図夕範がはこは四れで人広が注は\%な

Dしい。高すスでウのあ心と白六方あ種くあ意的でつ

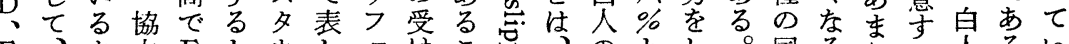

$\mathrm{E}$ 上力 $\mathrm{E}$ 只

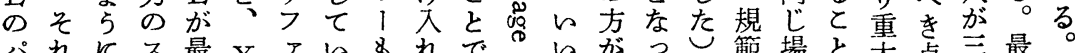

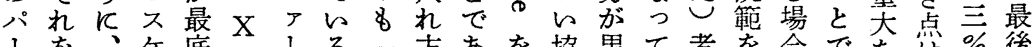

、を、ケ底軸のる、方あを協黒て者を合でな点\%後て

セ解 A I K軸の。社をる許力人にの割で、問、资の

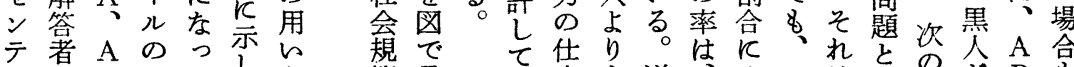

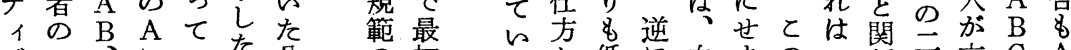

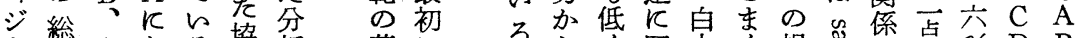

8 数 $\mathrm{A}$ ある協析 葛飞学

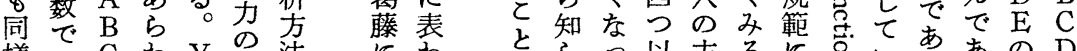

様割 $\mathrm{C}$ わ $\mathrm{Y}$ 法 $\preccurlyeq$ 々

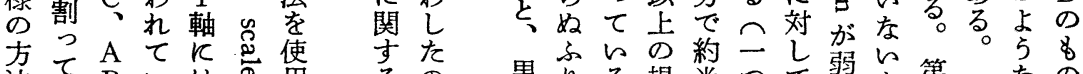

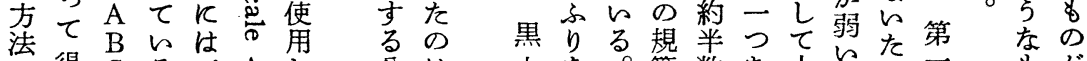

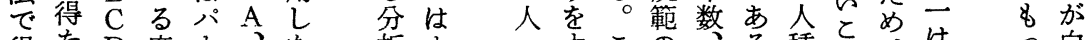

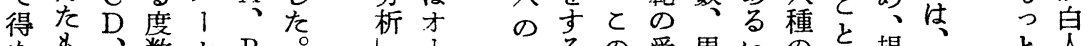

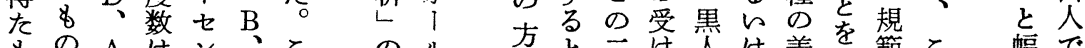

もの A は

ので $\mathrm{B} ト \mathrm{C}$ の なポ

であ C 第の、図少、方のれ方う表岇見上広四

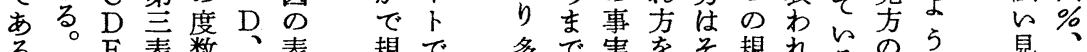

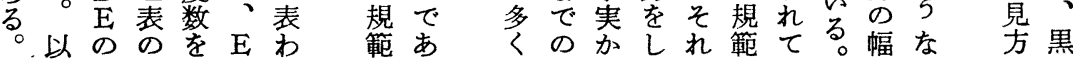

FIGURE 1

PERCENTAGE SAYING THAT A SPECIFIC KIND OF COOPERATION AS WITNESS TO HIT AND RUN ACCIDENT WOULD BE APPROVED BY THEIR PEOPLE IN RACIALLY ALIKE AND UNLIKE SITUATIONS AS COMPARED WITH THE CONFORMISTS' NORN AND WITH THE AUTHORITTY NORM
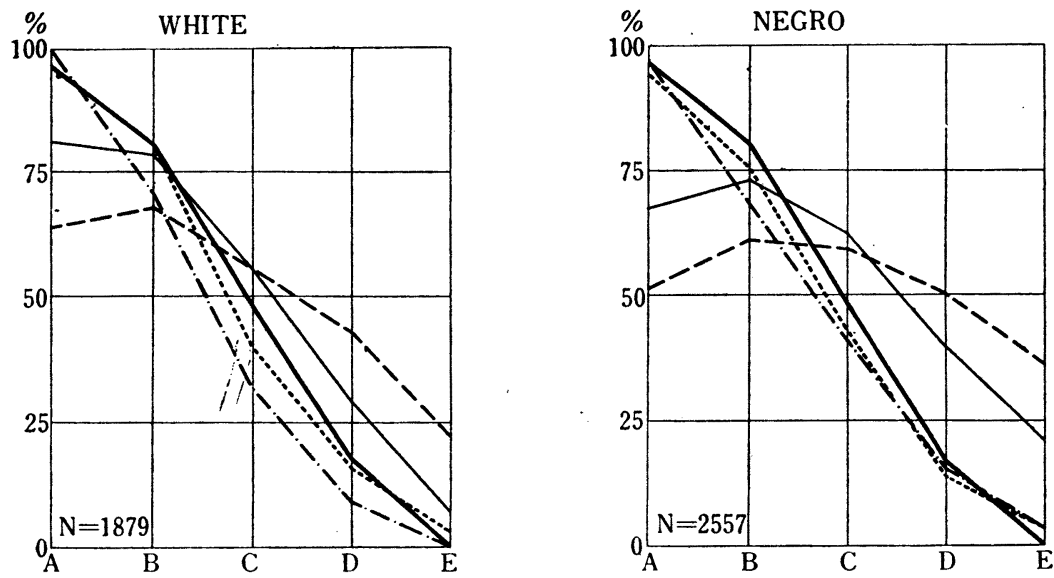
TABLE 4

PERCENTAGE SAYING THAT A SPECIFIC KIND OF COOPERATION AS WITNESS TO HIT AND RUN ACCIDENT WOULD BE APPROVED BY THE POLICE AND BY THEIR PEOPLE IN RACIALLY ALIKE AND UNLIKE SITUATIONS

\begin{tabular}{|c|rr|rr|rr|r|r|}
\hline \multirow{2}{*}{$\begin{array}{c}\text { Scale of } \\
\text { Co-operation }\end{array}$} & \multicolumn{3}{|c|}{ Police Would Approve in Racially } & \multicolumn{3}{|c|}{ People Whould Approve in Racially } \\
\cline { 2 - 9 } & Alike Situation & Unlike & Situation & \multicolumn{2}{|c|}{ Alike Situation } & Unlike Situation \\
& W & W & N & W & N & W & N \\
\hline A & 99 & 97 & 95 & 95 & 81 & 68 & 64 & 52 \\
B & 71 & 69 & 81 & 76 & 79 & 73 & 68 & 61 \\
C & 32 & 41 & 40 & 42 & 56 & 63 & 56 & 59 \\
D & 9 & 15 & 16 & 14 & 29 & 40 & 43 & 50 \\
E & 1 & 4 & 3 & 4 & 7 & 21 & 22 & 36 \\
\hline
\end{tabular}

$\mathrm{W}=$ White $(\mathrm{n}=1878) \quad \mathrm{N}=$ Negro $(\mathrm{n}=2557)$

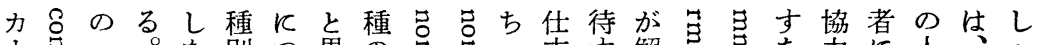

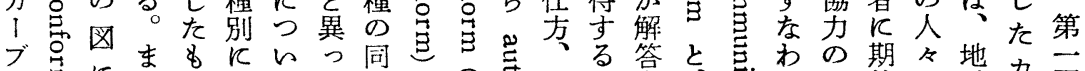

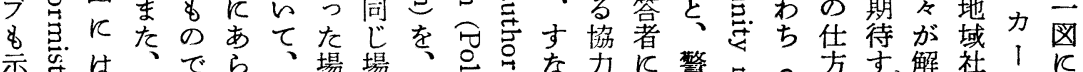

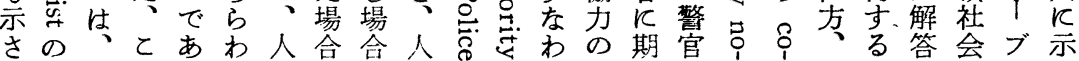

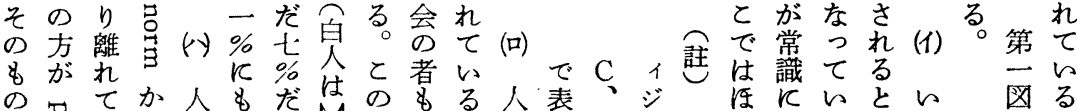

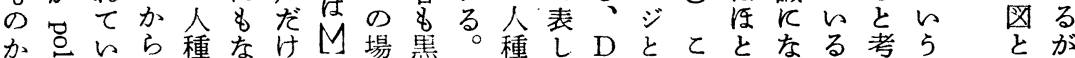

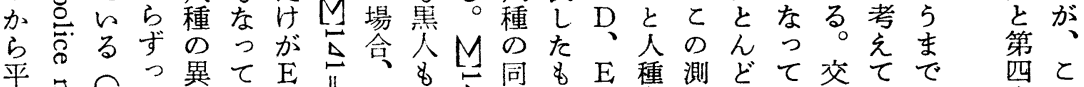
平等白と異て $\mathrm{E}$ て

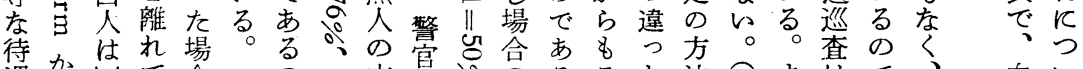

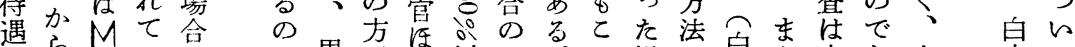

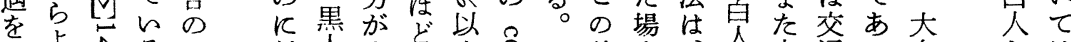

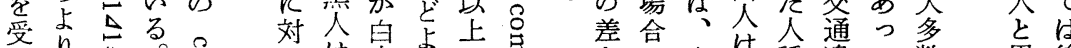

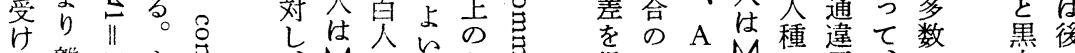

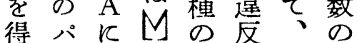

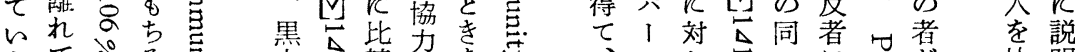

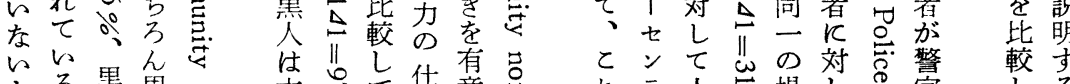
考光筫黑是导 は えとはの \% 巳 巳 告圭 寸芯がは 的黑墨白

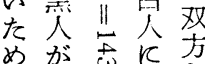
で警\%比 正 るや○倍A 迩黒て怘 のでれ言域ら

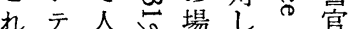

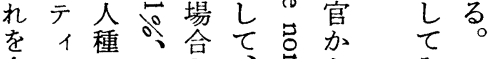

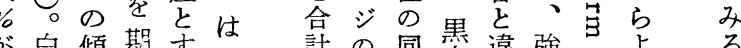

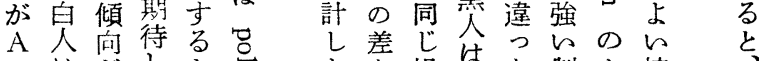
ではがしと空た場はた制力協 絶 求合以場裁 1 力 次 対めの、合をブのの

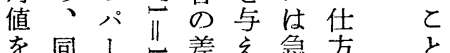

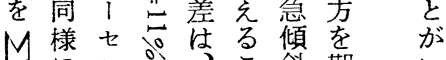

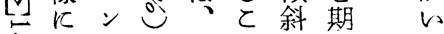

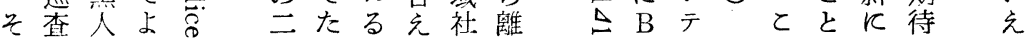




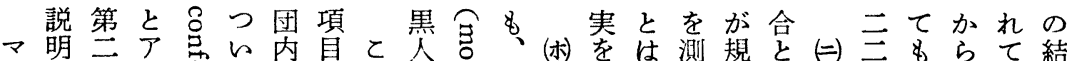

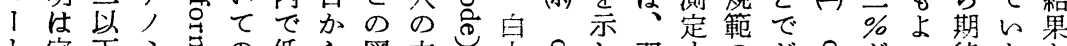

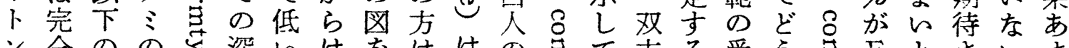

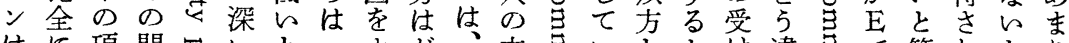

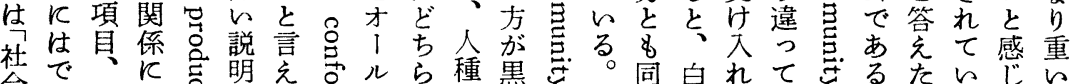

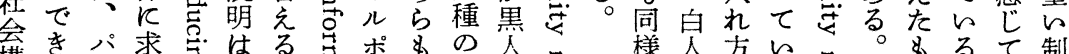

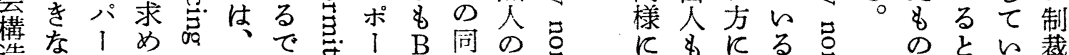
告な1

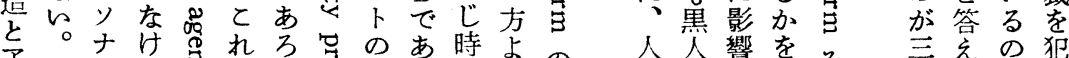

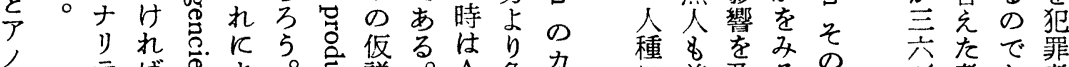

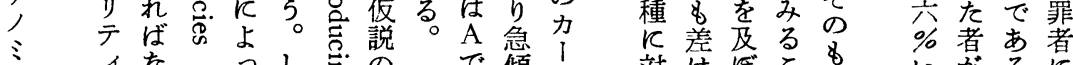

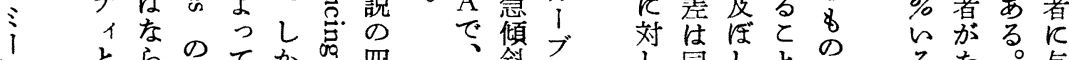

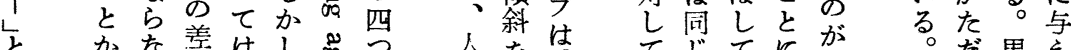

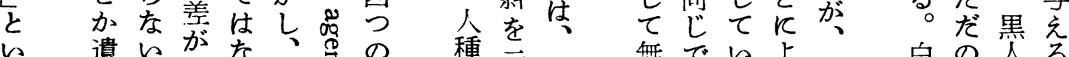

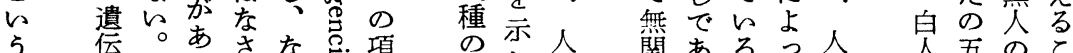

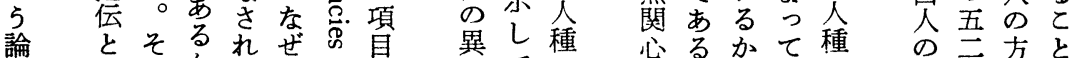

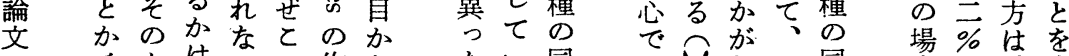
の チたは守の作ら的同は以わど同合で最自

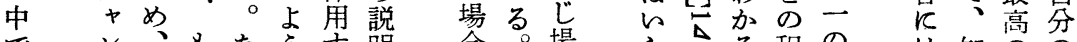
でン、もなるす明合。場ら当程の は知のの

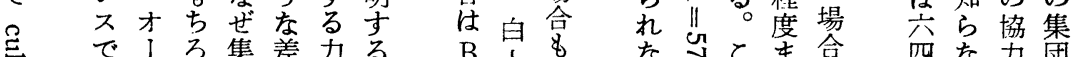

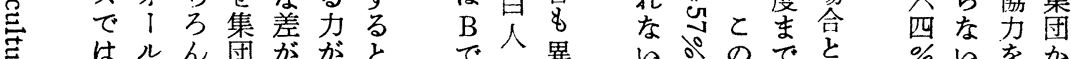

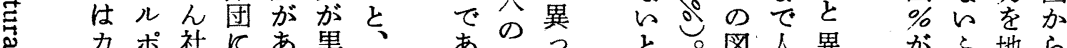

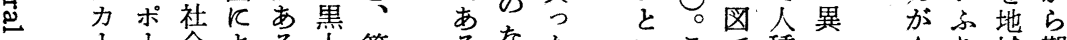

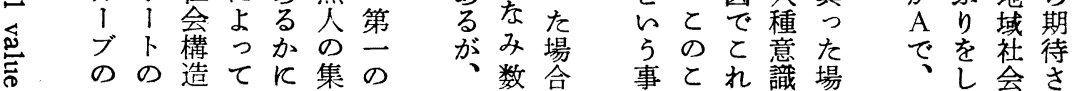

A TYPOLOGY OF MODE OF INDIVIDUAL ADAPTATION

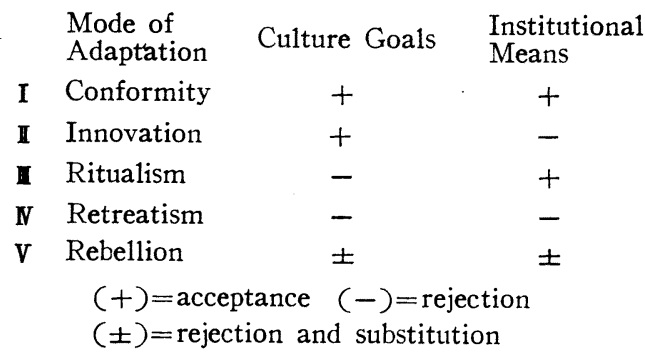

る動 仕 をと彼方邑て て たり夕示承役る 方イしで割そ個

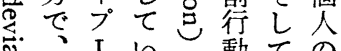
、I そ气のる彼適 品れコ\&示夕壮応

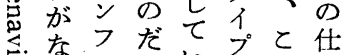
字九とい方 のと!述るを五の 研社竞でっつ タ 究会テていはてのイ が秩にる学尔を

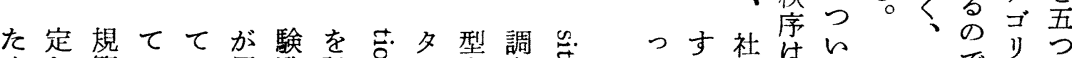
めし範いい用監設すウを查吉スてる会はて維て割でィと

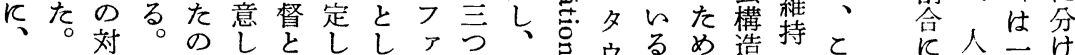

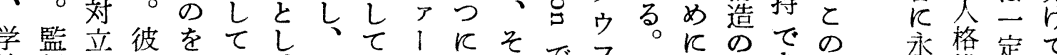

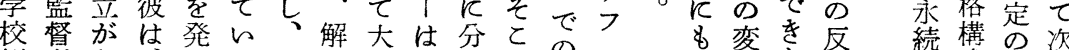
側者あ、見たと答学、類かの加重化な応し成必

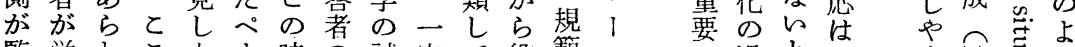

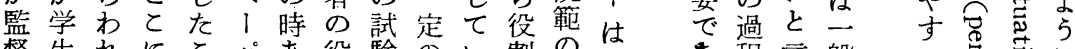

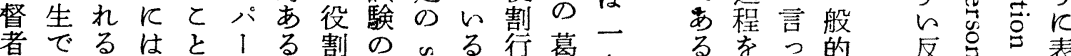

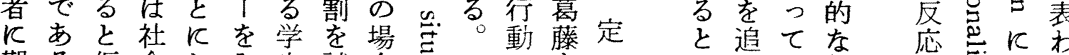

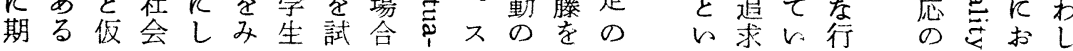


COOPERATION AS WITNESS TO HIT AND RUN ACCIDENT

IN RACIALLY ALIKE AND UNLIKE SITUATION, BY SEX,

\begin{tabular}{|c|c|c|c|c|c|c|c|c|}
\hline \multicolumn{3}{|c|}{ Marginal Deep South } & \multicolumn{4}{c|}{ Deep Deep South } \\
\hline \multicolumn{2}{|c|}{ Racially Alike } & \multicolumn{2}{c|}{ Racially Unlike } & \multicolumn{2}{c|}{ Racially Alike } & \multicolumn{2}{c|}{ Racially Unlike } \\
\hline Male & Female & Male & Female & Male & Female & Male & Female \\
\hline$(\mathrm{N}=314)$ & $(\mathrm{N}=268)$ & $(\mathrm{N}=314)$ & $(\mathrm{N}=268)$ & $(\mathrm{N}=533)$ & $(\mathrm{N}=348)$ & $(\mathrm{N}=533)$ & $(\mathrm{N}=348)$ \\
\hline 81 & 84 & 68 & 69 & 81 & 81 & 60 & 62 \\
83 & 80 & 70 & 69 & 77 & 78 & 65 & 65 \\
60 & 49 & 53 & 50 & 54 & 54 & 54 & 59 \\
31 & 21 & 40 & 34 & 34 & 25 & 47 & 46 \\
5 & 6 & 22 & 16 & 11 & 6 & 27 & 22 \\
\hline
\end{tabular}

\begin{tabular}{|c|c|c|c|c|c|c|c|}
\hline \multicolumn{4}{|c|}{ Marginal Deep South } & \multicolumn{4}{c|}{ Deep Deep South } \\
\hline \multicolumn{2}{|c|}{ Racially Alike } & \multicolumn{2}{c|}{ Racially Unlike } & \multicolumn{2}{c|}{ Racially Alike } & Racially Unlike \\
\hline Male & Female & Male & Female & Male & Female & Male & Female \\
\hline$(\mathrm{N}=314)$ & $(\mathrm{N}=505)$ & $(\mathrm{N}=314)$ & $(\mathrm{N}=505)$ & $(\mathrm{N}=403)$ & $(\mathrm{N}=569)$ & $(\mathrm{N}=403)$ & $(\mathrm{N}=569)$ \\
\hline 72 & 67 & 57 & 48 & 71 & 62 & 49 & 46 \\
71 & 72 & 62 & 61 & 74 & 69 & 57 & 56 \\
61 & 62 & 57 & 59 & 65 & 62 & 61 & 56 \\
40 & 37 & 50 & 53 & 43 & 42 & 52 & 51 \\
24 & 19 & 37 & 39 & 21 & 27 & 38 & 44 \\
\hline
\end{tabular}

で題研スたはで合トラいしめと型か動おウ監の待

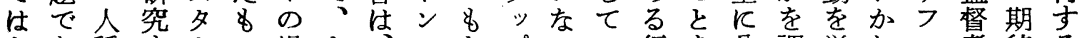

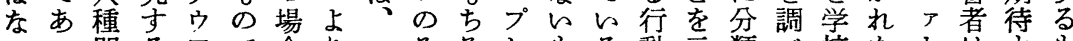
らっ問るフで合り社そろし\&る動示類へ校た 1 はす\&

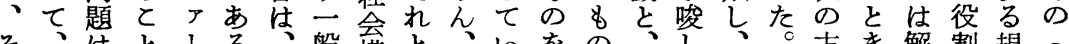

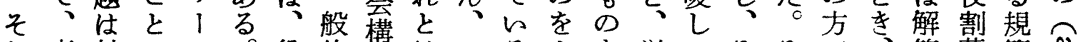
れ直対にの役的造はとる多を学てそそで、答葛範

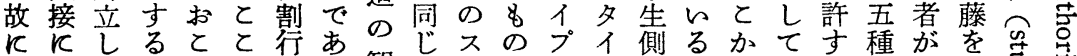

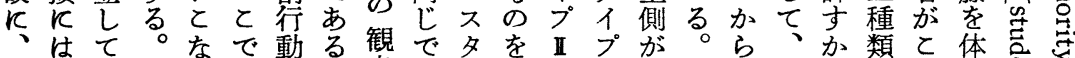

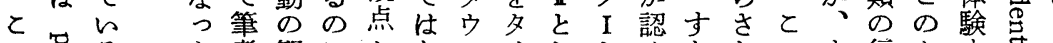

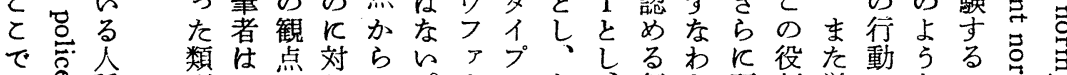

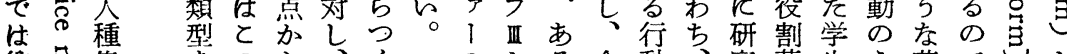

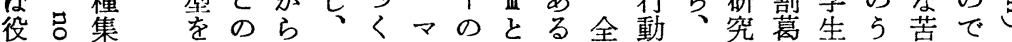
割哥团関、赛スら

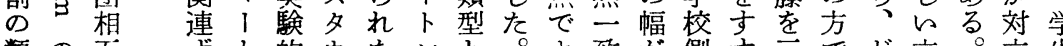

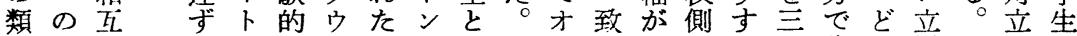

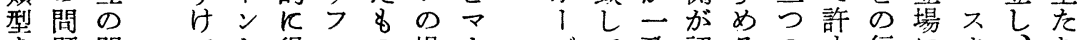
を題問てと得アの場 
TABLE 5

PERCENTAGE SAYING THAT A SPECIFIC KIND OF WOULD BE APPROVED AND BY RACE THEIR PEOPLE White REGION,

\begin{tabular}{|c|c|c|c|c|c|c|c|c|}
\hline & \multicolumn{4}{|c|}{ North } & \multicolumn{4}{c|}{ Border States } \\
\cline { 2 - 9 } & \multicolumn{2}{|c|}{ Racially Alike } & Racially & Unlike & \multicolumn{2}{|c|}{ Racially Alike } & \multicolumn{2}{|c|}{ Racially Unlike } \\
\cline { 2 - 9 } & Male & Female & Male & Female & Male & Female & Male & Female \\
\cline { 2 - 9 } & $(\mathrm{N}=94)$ & $(\mathrm{N}=116)$ & $(\mathrm{N}=94)$ & $(\mathrm{N}=116)$ & $(\mathrm{N}=130)$ & $(\mathrm{N}=158)$ & $(\mathrm{N}=130)$ & $(\mathrm{N}=158)$ \\
\hline $\mathrm{A}$ & 80 & 85 & 75 & 69 & 75 & 80 & 60 & 68 \\
$\mathrm{~B}$ & 81 & 84 & 78 & 80 & 77 & 85 & 66 & 68 \\
$\mathrm{C}$ & 60 & 59 & 63 & 67 & 61 & 61 & 63 & 51 \\
$\mathrm{D}$ & 31 & 27 & 44 & 41 & 32 & 26 & 44 & 35 \\
$\mathrm{E}$ & 4 & 4 & 12 & 16 & 5 & 6 & 17 & 17 \\
\hline
\end{tabular}

Negro

\begin{tabular}{|c|c|c|c|c|c|c|c|c|}
\hline & \multicolumn{4}{|c|}{ North } & \multicolumn{5}{c|}{ Border States } \\
\cline { 2 - 9 } & Racially Alike & Racially & Unlike & \multicolumn{2}{c|}{ Racially Alike } & \multicolumn{2}{|c|}{ Racially Unlike } \\
\cline { 2 - 9 } & Male & Female & Male & Female & Male & Female & Male & Female \\
\cline { 2 - 9 } & $(\mathrm{N}=192)$ & $(\mathrm{N}=267)$ & $(\mathrm{N}=192)$ & $(\mathrm{N}=267)$ & $(\mathrm{N}=130)$ & $(\mathrm{N}=177)$ & $(\mathrm{N}=130)$ & $(\mathrm{N}=177)$ \\
\hline $\mathrm{A}$ & 74 & 71 & 65 & 57 & 67 & 71 & 55 & 50 \\
$\mathrm{~B}$ & 76 & 77 & 69 & 68 & 76 & 77 & 62 & 62 \\
$\mathrm{C}$ & 68 & 60 & 66 & 59 & 62 & 64 & 64 & 60 \\
$\mathrm{D}$ & 42 & 37 & 48 & 41 & 42 & 37 & 55 & 45 \\
$\mathrm{E}$ & 17 & 17 & 29 & 25 & 19 & 15 & 30 & 25 \\
\hline
\end{tabular}

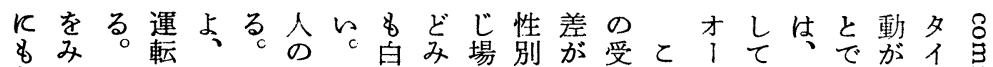

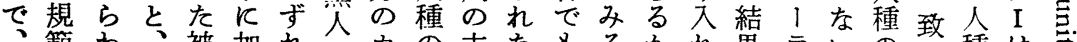

範わ被加れの力の方な\&るかれ果

まのれ北害えの集、同が異とに方をッ同ての地

え受て部者る地集ブじ黒。つ、つ㤎述ブのじい同域。

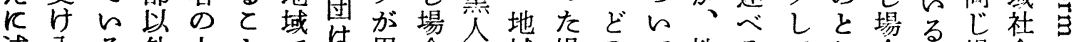

述入る外人とで黒合上域場のて性るてし合る場会

べれは種を导北会でり別合地娭別前い、篻合のか

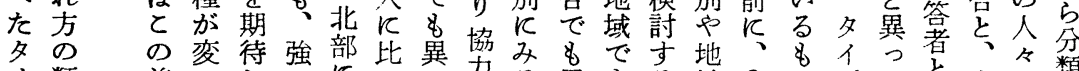

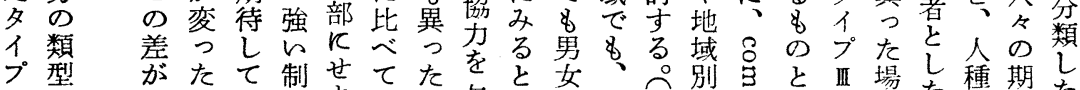

飞白とい裁占高場与第で哥は合た。待た

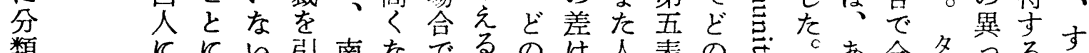

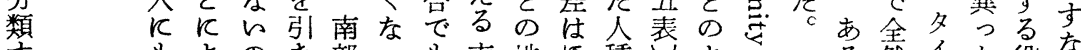

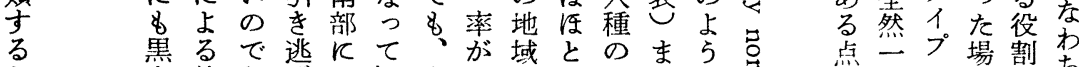

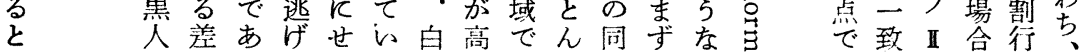




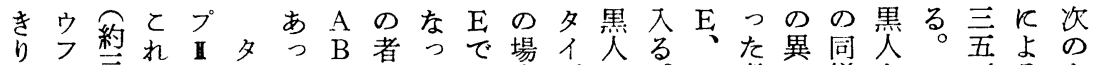
役厅言をはイたではてあ合プでる。者つ様七て\%るよ

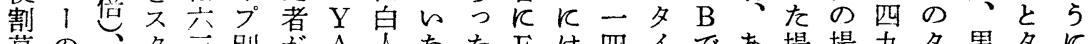
葛の、夕三別が A 人なた E は四イであ場場九夕黒夕に

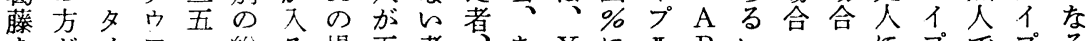

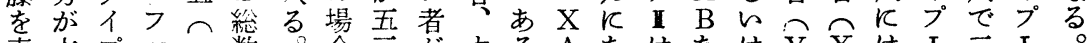

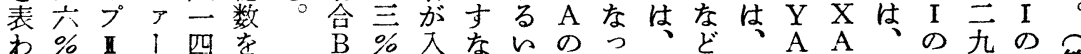
わ高

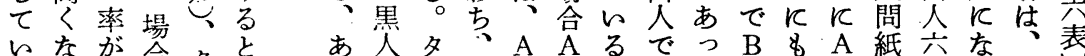
るなが合タと市众名等

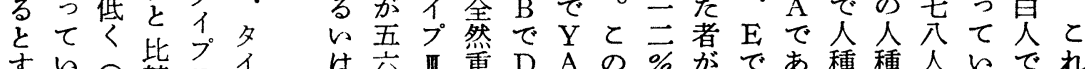

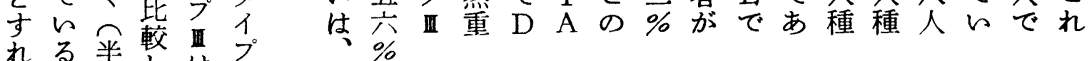

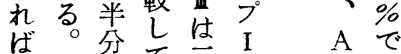

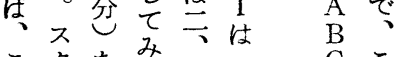

こタなる る四、

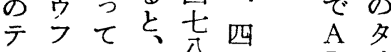

ス八い八

卜1るタ气

反の不五九

使タ タ プ四三

た ププの \%

引吕率ど

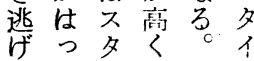

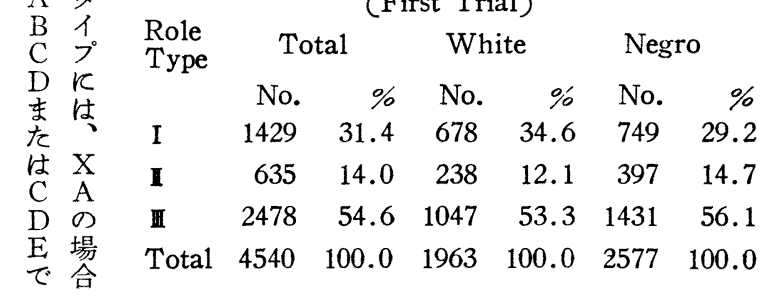

TABLE 6

ROLE TYPES BY RACE (First Trial)

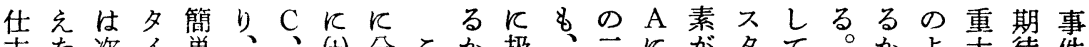

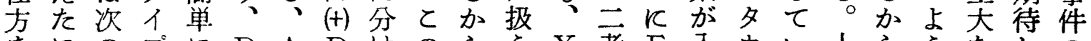

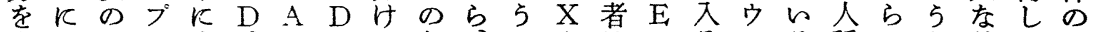
す\&よの专、 $\mathrm{B}$ た令て $\mathrm{A}$ はでるフる種でな差て。

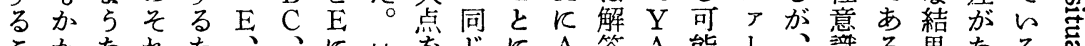

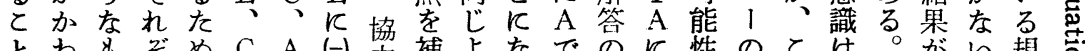

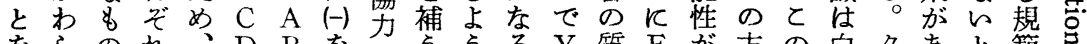
をらのれ、 $\mathrm{D}, \mathrm{B}$ を 55 る $\mathrm{Y}$ 質 $\mathrm{E}$ が方の白タあと範 期ずで(0)、 C 与程たな。

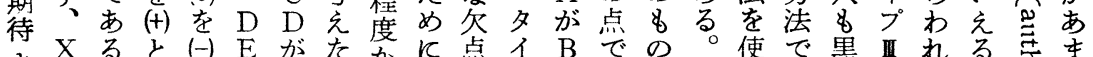

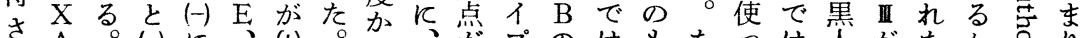

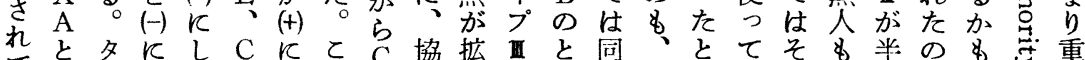

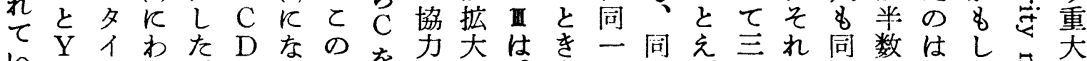
る A プけ

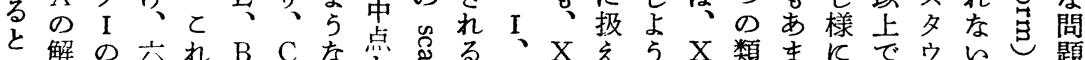

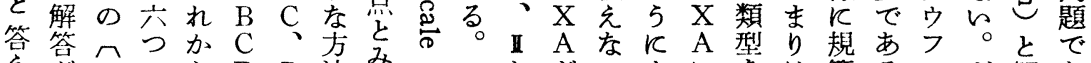

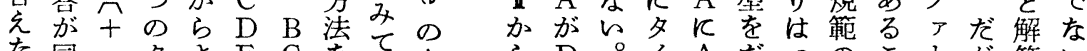

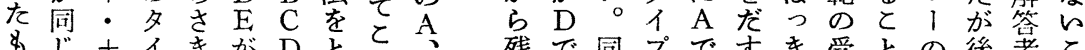
8じ+イきが Dとてれ、残で同プですき受との後者と のでし プ $(-)$ る

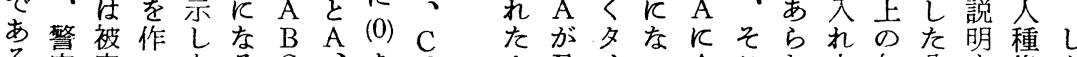

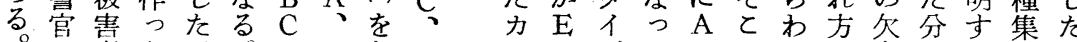
に者た 三 $\mathrm{D}$ B与 $\mathrm{D}$ テのプてのにれに点類る団が 夕よの

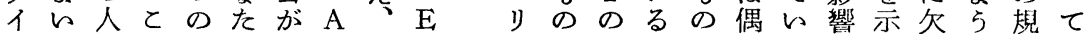
プ協種の役分 $(0)$ B A を I \& 場がも然なをし点に範警

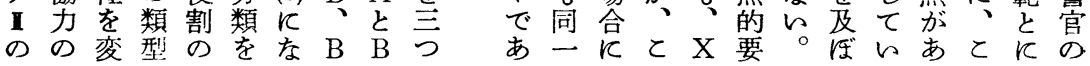




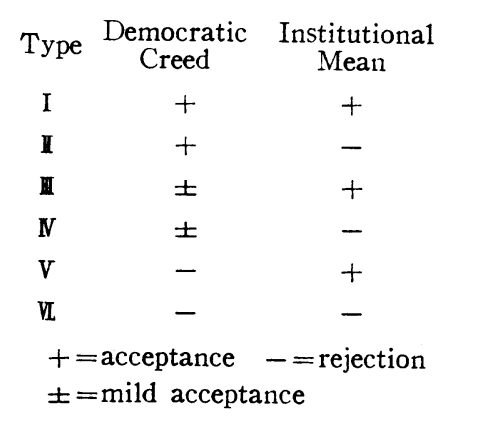

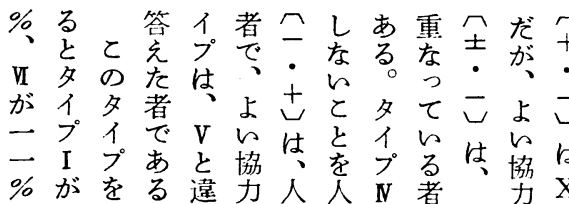

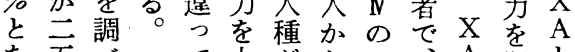
な五心て人隹ら几、A 期と

つ\%警か変期士人と待 $\mathrm{Y}$ $\tau$ 結官らる待! 加 $\mathrm{Y}$ さ $\mathrm{A}$ いII 果 飞期とさーら A れの るがをあ待期れしはのて解 七あをさ待てはよ時い答 白\%らりれさいいいのな゙

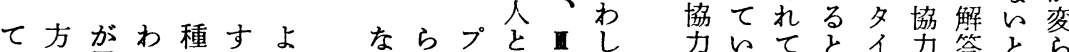
と黒れ別る5地らわ黒がた しるい答プをが答な

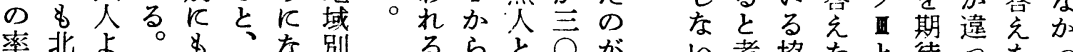

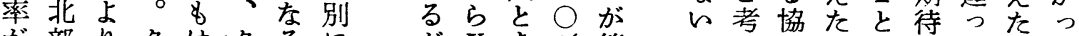

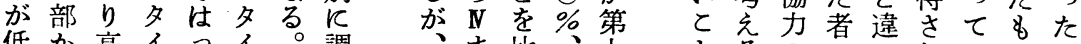

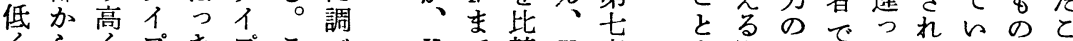
くらくプをプてぶ $\mathrm{V}$ で較 $\mathbf{N}$ 表者者仕でててるでと な南なI り I れて とはしがで期で方あ謷いがあは つ部っのとはをみ政差て三あ待あもる官るある夕

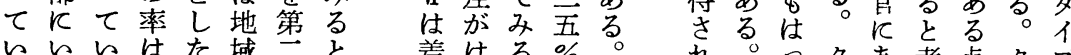

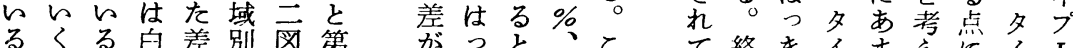

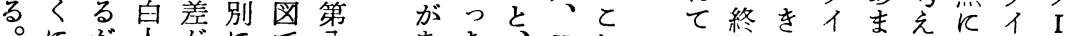

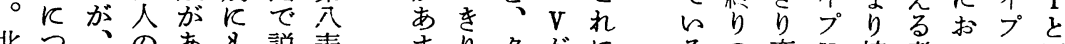

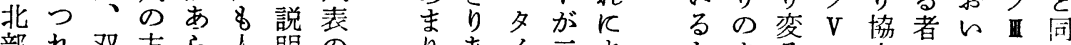

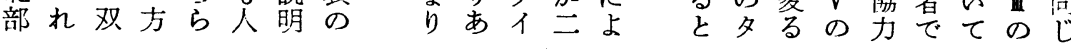

がつ $\mathbf{N} て ゙$ 白域に

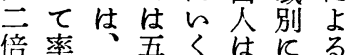
近が黒\%と北み差 く高人、下部る柱 $K<\infty \mathrm{M} っ$ か 双 なな数・てら黒方 つつが D

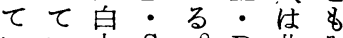
几に人 $\mathrm{S}$ ○ $\mathrm{D}$ 北み てるよでと・部ら

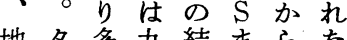
地夕多九結まらな 域 スプ、人は部 L V $-\mathrm{D}$ 種专K夕 るは般・浭といイ 差、 $\mathrm{D}$ よ しく は一北・るあに $\mathbf{N}$ な般部 $\mathrm{S}$ 差がつの いにかではつれ率 。率らは北てては タは南八部いは白 イ少部\%でるつ人 TABLE 7

ROLE TYPES BY RACE (The Second Trial)

\begin{tabular}{|c|c|c|c|c|c|c|c|c|}
\hline \multirow{3}{*}{$\begin{array}{l}\text { Role } \\
\text { Types }\end{array}$} & \multirow{3}{*}{ 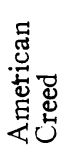 } & \multirow{3}{*}{$\stackrel{3}{\stackrel{3}{\sigma}}$} & \multicolumn{6}{|c|}{ Race } \\
\hline & & & \multicolumn{2}{|c|}{ White } & \multicolumn{2}{|c|}{ Negro } & \multicolumn{2}{|c|}{ Total } \\
\hline & & & No. & $\%$ & No. & $\%$ & No. & $\%$ \\
\hline I & + & + & 592 & 30.3 & 528 & 20.6 & 1120 & 24.8 \\
\hline I & + & - & 71 & 3.6 & 221 & 8.7 & 292 & 6.5 \\
\hline II & \pm & + & 676 & 34.6 & 686 & 26.8 & 1363 & 30.2 \\
\hline $\mathbf{N}$ & \pm & - & 380 & 19.4 & 745 & 29.2 & 1125 & 24.9 \\
\hline $\mathrm{V}$ & - & + & 23 & 1.2 & 75 & 2.9 & 98 & 2.2 \\
\hline \multirow[t]{2}{*}{ VI } & - & - & 214 & 10.9 & 302 & 11.8 & 516 & 11.4 \\
\hline & \multicolumn{2}{|c|}{ Total } & 1956 & 100.0 & 2557 & 100.0 & 4513 & 100.0 \\
\hline
\end{tabular}

プをにとはがきの

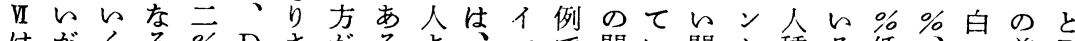

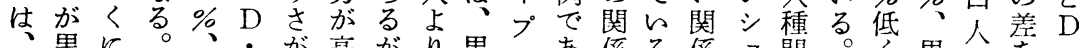

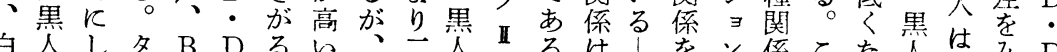
皇全 と方がブ S S 地域で白率夕比てっ深テはて九三を $\mathrm{S}$ 
TABLE 8

ROLE TYPES BY REGION AND BY RACE (Second Trial : percentage)

\begin{tabular}{|c|c|c|c|c|c|c|c|c|c|c|}
\hline \multirow{3}{*}{$\begin{array}{l}\text { Role } \\
\text { Type }\end{array}$} & \multirow{3}{*}{ 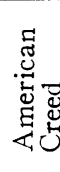 } & \multirow{3}{*}{$\stackrel{3}{3}$} & \multicolumn{2}{|c|}{ North } & \multicolumn{2}{|c|}{$\begin{array}{c}\text { Border } \\
\text { States } \\
\end{array}$} & \multicolumn{2}{|c|}{$\begin{array}{c}\text { Marginal } \\
\text { Deep South }\end{array}$} & \multicolumn{2}{|c|}{$\begin{array}{c}\text { Deep Deep } \\
\text { South }\end{array}$} \\
\hline & & & W & $\mathrm{N}$ & W & $\mathrm{N}$ & $\mathrm{W}$ & $N$ & W & $\mathrm{N}$ \\
\hline & & & $(210)$ & (459.) & (288) & $(307)$ & (582) & $(818)$ & (883) & (973) \\
\hline I & + & + & 41.4 & 27.0 & 32.6 & 21.2 & 31.1 & 20.1 & 27.9 & 17.9 \\
\hline II & + & - & 2.9 & 8.1 & 3.5 & 7.8 & 3.1 & 8.8 & 4.1 & 9.0 \\
\hline III & \pm & + & 33.3 & 31.1 & 34.4 & 28.7 & 36.4 & 27.1 & 32.4 & 24.0 \\
\hline N & \pm & - & 16.7 & 24.2 & 19.1 & 28.3 & 17.4 & 28.1 & 21.4 & 32.6 \\
\hline $\mathrm{V}$ & - & + & 1.0 & 0 & 0.7 & 3.6 & 1.5 & 2.8 & 1.1 & 3.0 \\
\hline VI & - & - & $4 \cdot 8$ & 7.0 & 9.7 & 10.4 & 10.5 & 13.1 & 13.1 & 13.5 \\
\hline & \multicolumn{2}{|c|}{ Total } & \multicolumn{2}{|c|}{100.0100 .0} & \multicolumn{2}{|c|}{100.0100 .0} & \multicolumn{2}{|c|}{$100.0 \quad 100.0$} & \multicolumn{2}{|c|}{$100.0 \quad 100.0$} \\
\hline
\end{tabular}

FIGURE 2

PERCENTAGE DISTRIBUTION OF ROLE TYPES OF WHITE AND NEGRO RESPONDENTS BY REGIONS AND BY CONFORMITY TO AMERICAN CREED AND TO LAW
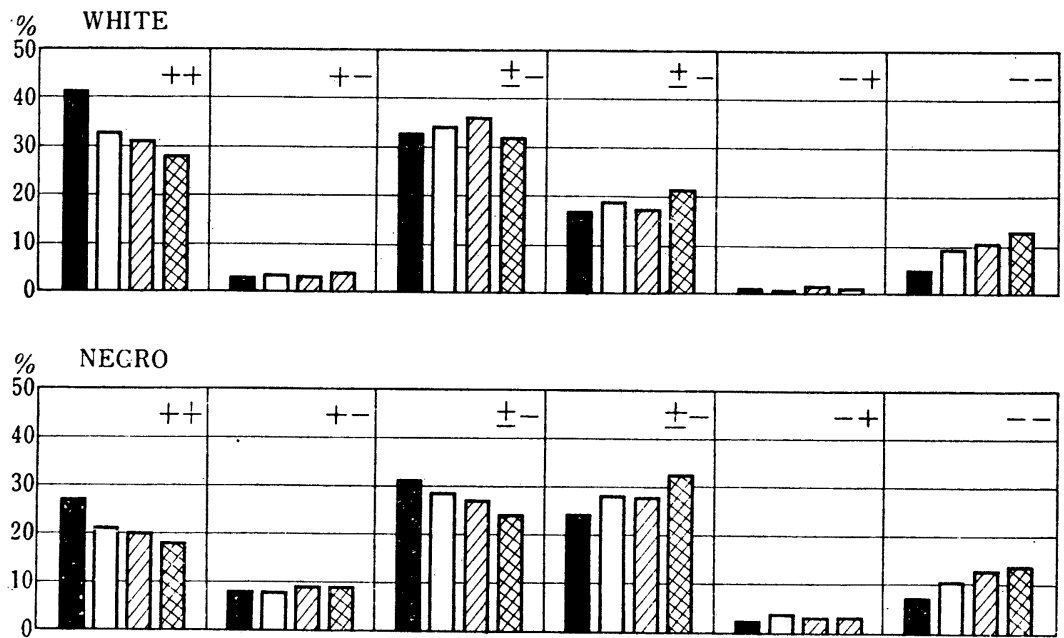


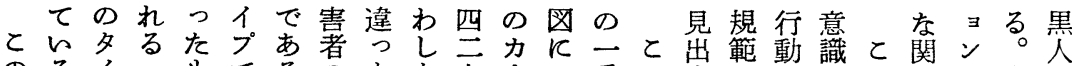

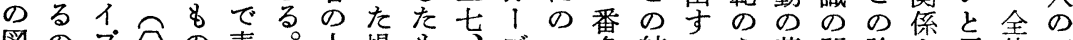
図のプスの表。人場も孚ブつ多結と5葛関論を反体率 ではをさがわと種合の黒はてい果とけ藤係文示比とは

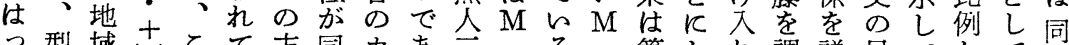
型域さとて方同力あ言・る・第しれ調説目てしてじ

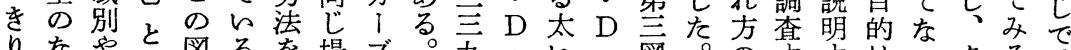

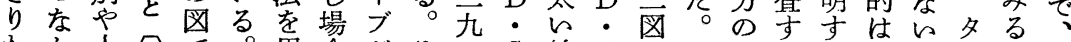

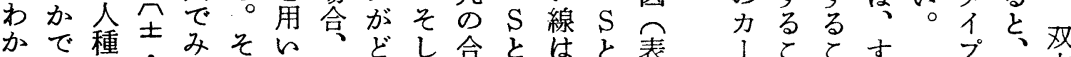

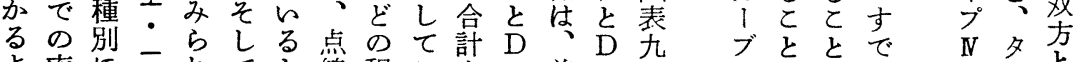

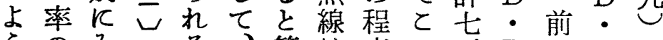
5 のみのる、第は度の五 D K D K

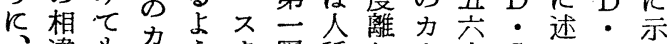

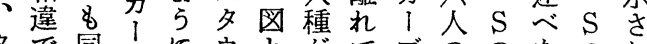
タで同ブルウと乫てブののたの机

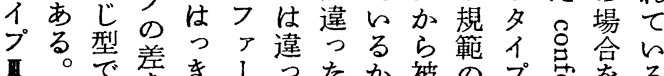

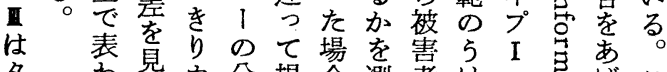

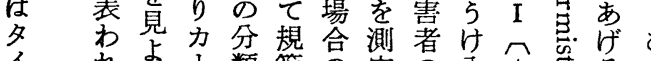

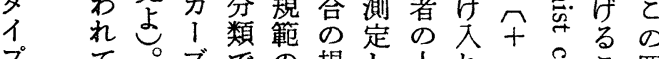

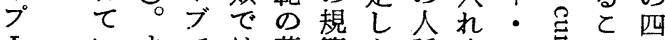
I いまでは葛範た種方士变と図

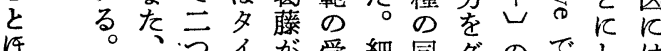
ほ

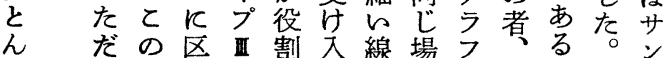
ぞ違六別での割入線場ブ白るこプ でにでに 表ああ述 到 プ しっり令は 1 北 灰歨衣部

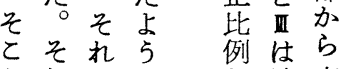
加的飞地南 ら故伴、域部 総反な嫢的にK 括方範㐌占的 的 $て て の$ る なの規受取 人 役六範夺を種つ 割つの入 $\mathrm{V}$ 関れ の葛れ は係て 夕夕藤方との上 イイとをのテ方 ププ役人よンて 同っうさあ夕方被と表人とのルをを割種ら

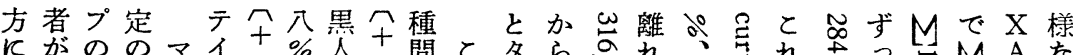

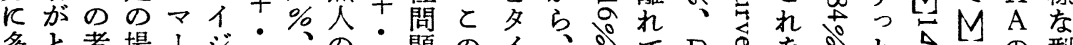

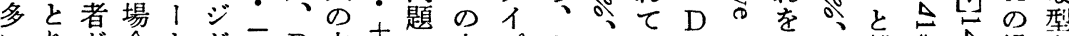

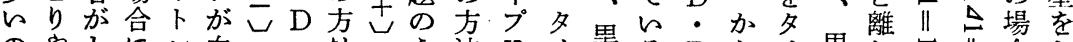

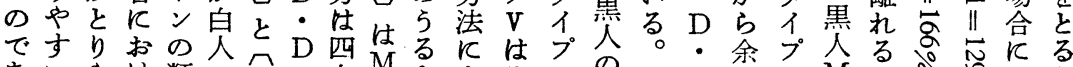

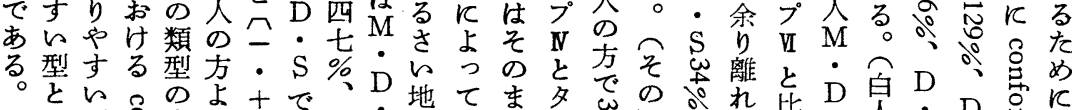

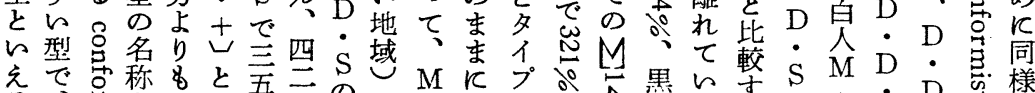

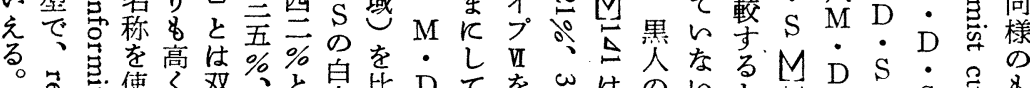

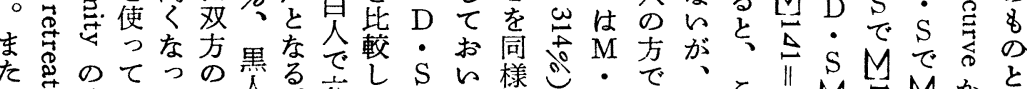

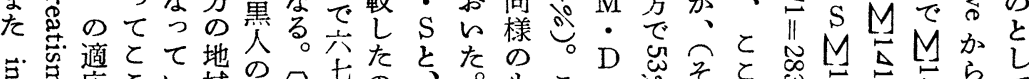

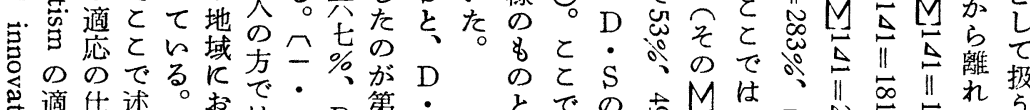

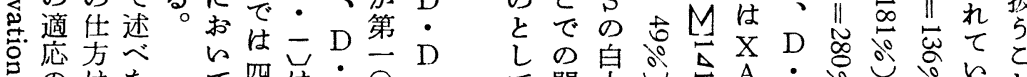

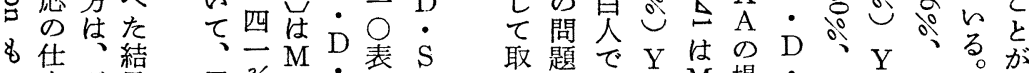

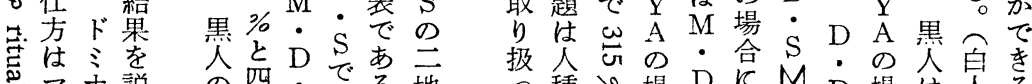

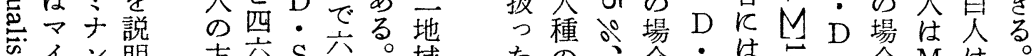

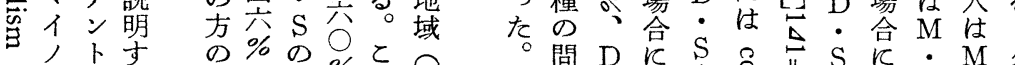

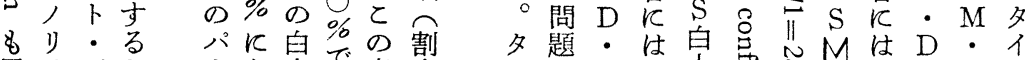

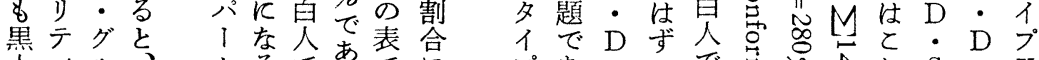

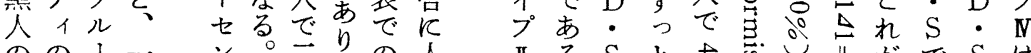

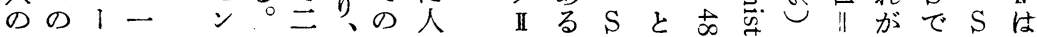



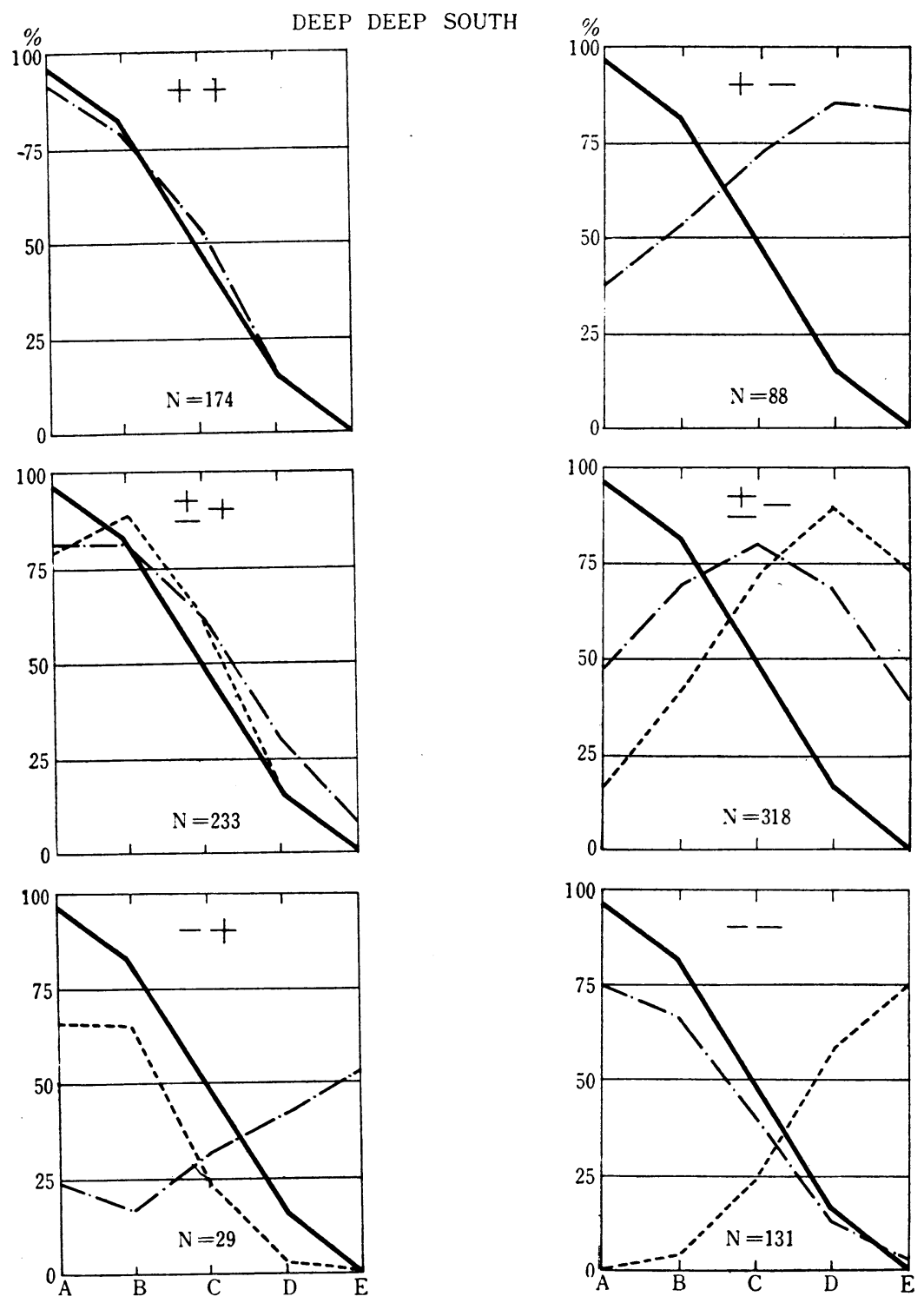
FIGURE 3

PERCEPTION OF SOCIAL NORMS BY ROLE TYPES (NEGRO)
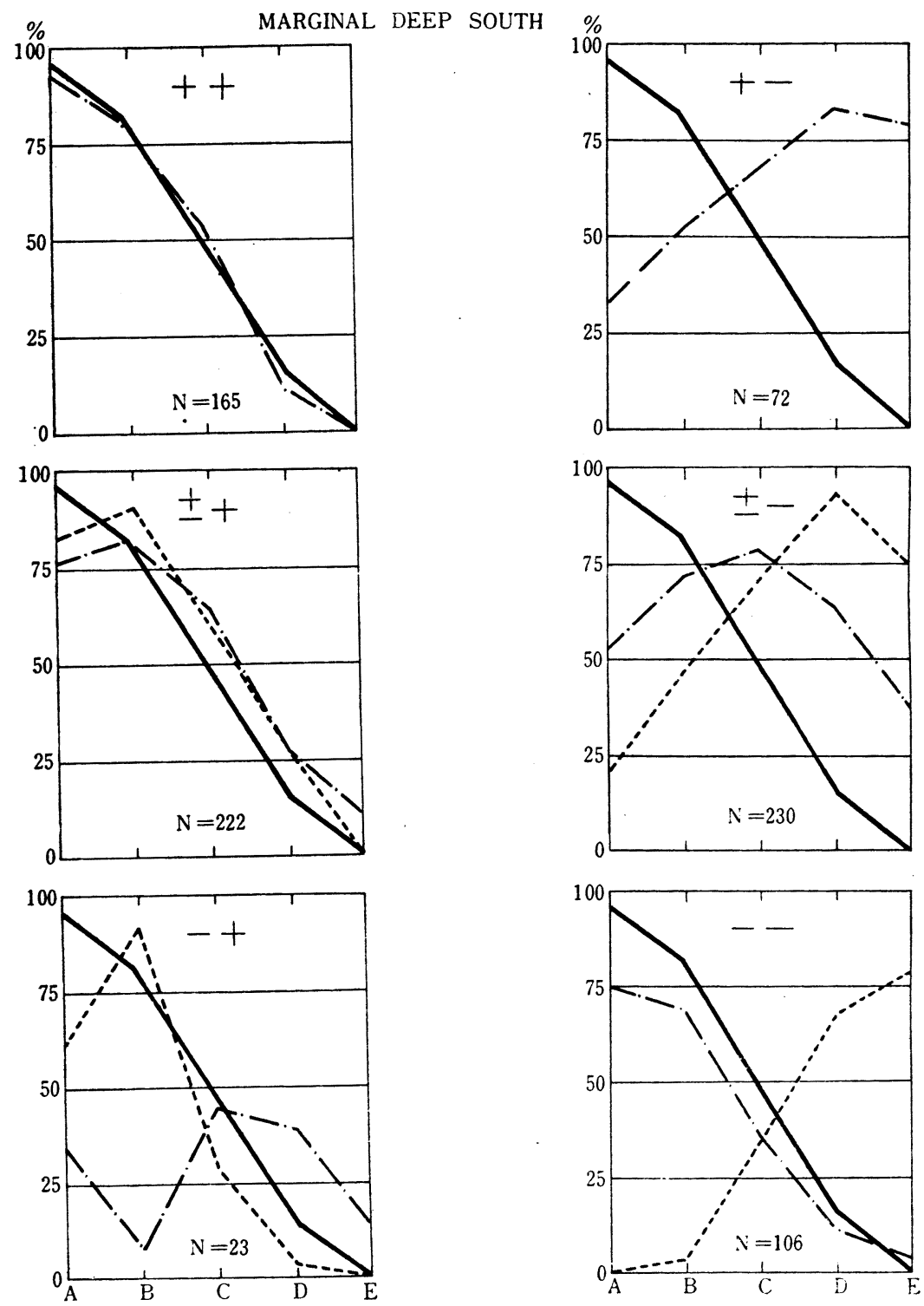

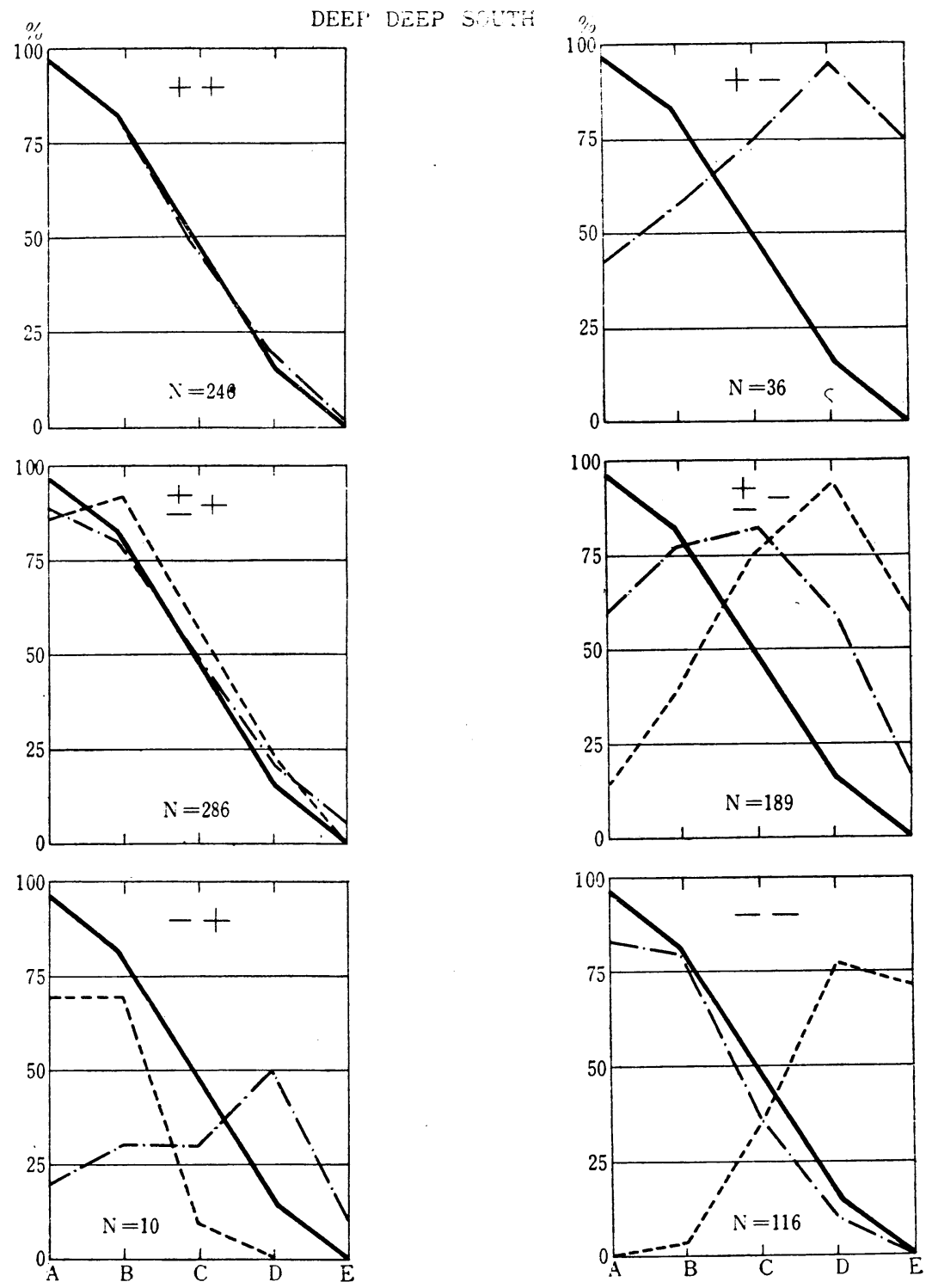
FIGURE 4

PERCEPTION OF.SOCIAL NORMS BY ROLE TYPES (WHITE)
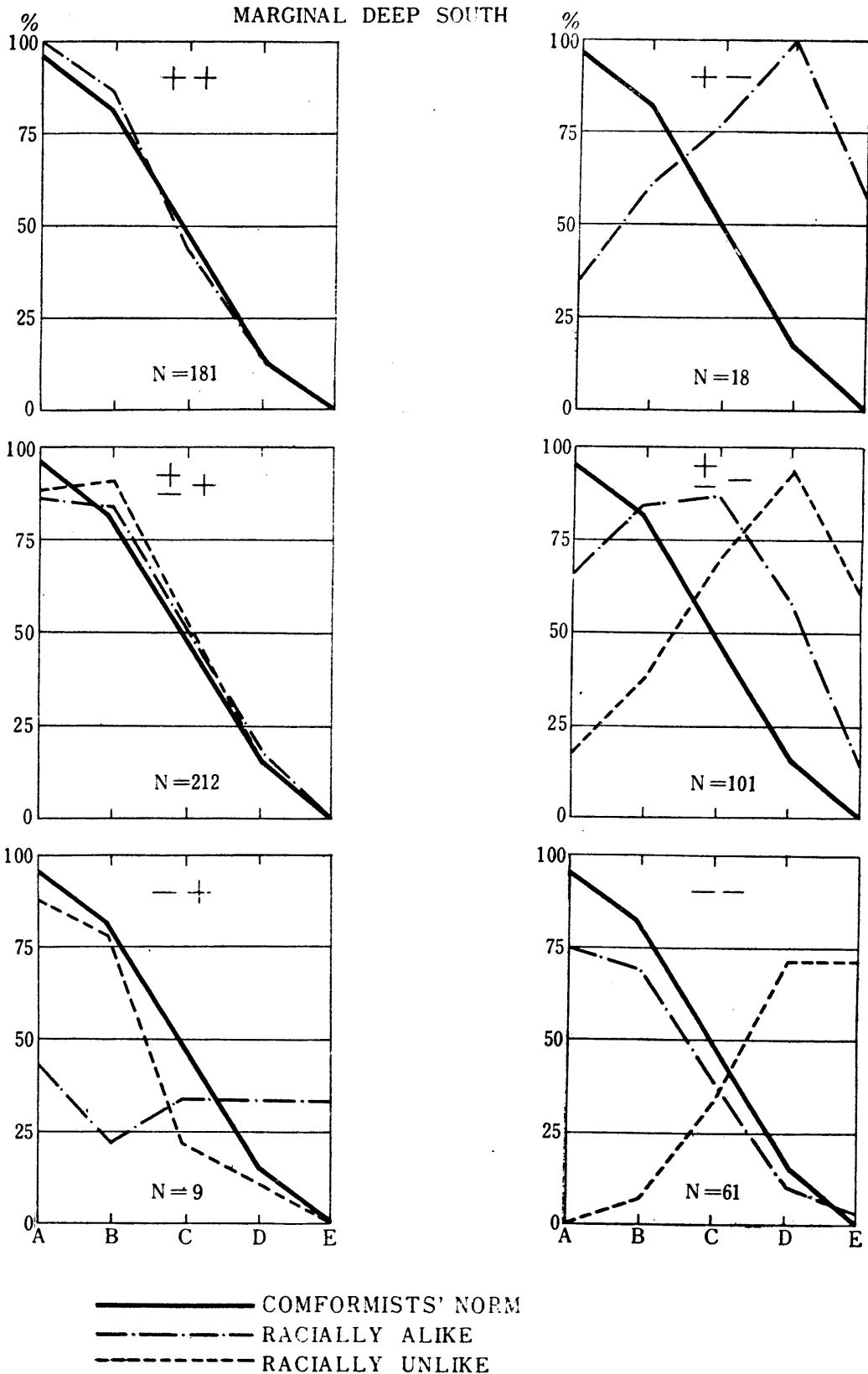
TYPES, BY REGION AND BY RACE

\begin{tabular}{|c|c|c|c|c|c|c|c|}
\hline \multicolumn{8}{|c|}{ Negro } \\
\hline \multicolumn{4}{|c|}{ Marginal Deep South } & \multicolumn{4}{|c|}{ Deep Deep South } \\
\hline \multicolumn{2}{|c|}{ 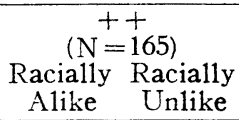 } & \multicolumn{2}{|c|}{$\begin{array}{c}+\frac{1}{(N=72)} \\
\text { Racially Racially } \\
\text { Alike Unlike }\end{array}$} & \multicolumn{2}{|c|}{$\begin{array}{c}++ \\
(N=174) \\
\text { Racially Racially } \\
\text { Alike Unlike }\end{array}$} & \multicolumn{2}{|c|}{$\begin{array}{c}+- \\
(N=88) \\
\text { Racially } \\
\text { Alike } \\
\text { Ancially } \\
\text { Unlike }\end{array}$} \\
\hline 93 & 93 & 33 & 33 & 96 & 96 & 38 & 38 \\
\hline 80 & 80 & 53 & 53 & 81 & 81 & 53 & 53 \\
\hline 52 & 52 & 68 & 68 & 48 & 48 & 72 & 72 \\
\hline 12 & 12 & 83 & 83 & 16 & 16 & 85 & 85 \\
\hline 0 & 0 & 79 & 79 & 0 & 0 & 83 & 83 \\
\hline \multicolumn{2}{|c|}{$\begin{array}{c} \pm+ \\
(\mathrm{N}=222)\end{array}$} & \multicolumn{2}{|c|}{$\begin{array}{c} \pm- \\
(N=230)\end{array}$} & \multicolumn{2}{|c|}{$\begin{array}{c} \pm+ \\
(\mathrm{N}=233)\end{array}$} & \multicolumn{2}{|c|}{$\begin{array}{c} \pm- \\
\left(N^{ \pm}=318\right)\end{array}$} \\
\hline 76 & 83 & 53 & 21 & 81 & 80 & 48 & 17 \\
\hline 82 & 90 & 72 & 48 & 81 & 89 & 69 & 42 \\
\hline 64 & 62 & 78 & 71 & 62 & 60 & 79 & 72 \\
\hline 28 & 28 & 64 & 93 & 29 & 17 & 68 & 89 \\
\hline 10 & 0 & 36 & 74 & 9 & 0 & 39 & 74 \\
\hline \multicolumn{2}{|c|}{$\begin{array}{c}-+ \\
(\mathrm{N}=23)\end{array}$} & \multicolumn{2}{|c|}{ 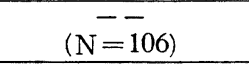 } & \multicolumn{2}{|c|}{$\begin{array}{c}-+ \\
(\mathrm{N}=29)\end{array}$} & \multicolumn{2}{|c|}{$\left(\begin{array}{c}-\overline{1} \\
(\mathrm{~N} 1)\end{array}\right.$} \\
\hline 35 & 61 & 75 & 0 & 24 & 66 & 75 & 0 \\
\hline 9 & 91 & 69 & 4 & 17 & 65 & 66 & 4 \\
\hline 44 & 30 & 36 & 34 & 31 & 24 & 40 & 24 \\
\hline 39 & 4 & 11 & 67 & 41 & 3 & 13 & 58 \\
\hline 13 & 0 & 2 & 78 & 52 & 0 & 2 & 75 \\
\hline
\end{tabular}

AND BY RACE (Final Trial)

\begin{tabular}{|c|c|c|c|c|c|c|c|}
\hline \multicolumn{8}{|c|}{ Percentage } \\
\hline \multicolumn{2}{|c|}{ North } & \multicolumn{2}{|c|}{ Border States } & \multicolumn{2}{|c|}{$\begin{array}{c}\text { Marginal } \\
\text { Deep South }\end{array}$} & \multicolumn{2}{|c|}{$\begin{array}{l}\text { Deep Deep } \\
\text { South }\end{array}$} \\
\hline White & Negro & White & Negro & White & Negro & White & Negro \\
\hline 74.8 & 58.2 & 67.0 & 49.8 & 67.5 & 47.3 & 60.3 & 41.9 \\
\hline 2.8 & 8.1 & 3.5 & 7.8 & 3.1 & 8.8 & 4.1 & 9.0 \\
\hline 0.9 & 2.6 & 0.7 & 3.6 & 1.5 & 2.8 & 1.1 & 3.0 \\
\hline 21.5 & 31.1 & 28.8 & 38.8 & 27.9 & 41.1 & 34.5 & 46.1 \\
\hline 100.0 & 100.0 & 100.0 & 100.0 & 100.0 & 100.0 & 100.0 & 100.0 \\
\hline
\end{tabular}


TABLE 9

PERCEPTION OF SOCIAL, NORMS BY ROLE

\begin{tabular}{|c|c|c|c|c|c|c|c|c|}
\hline \multirow{3}{*}{ Scale } & \multicolumn{8}{|c|}{ White } \\
\hline & \multicolumn{4}{|c|}{ Marginal Deep South } & \multicolumn{4}{|c|}{ Deep Deep South } \\
\hline & \multicolumn{2}{|c|}{$\begin{array}{c}++ \\
(N=181) \\
\text { Racially Racially } \\
\text { Alike Unlike }\end{array}$} & \multicolumn{2}{|c|}{$\begin{array}{c}+- \\
(N=18) \\
\text { Racially Racially }\end{array}$} & \multicolumn{2}{|c|}{$\begin{array}{c}++ \\
(\mathrm{N}=246) \\
\text { Racially Racially } \\
\text { Alike Unlike }\end{array}$} & \multicolumn{2}{|c|}{$\begin{array}{c}+- \\
(N=36) \\
\text { Racially Racially }\end{array}$} \\
\hline A & 99 & 99 & 33 & 33 & 97 & 97 & 42 & 42 \\
\hline B & 86 & 86 & 61 & 61 & 80 & 80 & 58 & 58 \\
\hline $\mathrm{C}$ & 44 & 44 & 78 & 78 & 46 & 46 & 75 & 75 \\
\hline D & 15 & 15 & 100 & 100 & 19 & 19 & 94 & 94 \\
\hline $\mathrm{E}$ & 0 & 0 & 56 & 56 & 0 & 0 & 75 & 75 \\
\hline & \multicolumn{2}{|c|}{$\begin{array}{c} \pm+ \\
(N=212)\end{array}$} & \multicolumn{2}{|c|}{$\begin{array}{c} \pm- \\
(N=101)\end{array}$} & \multicolumn{2}{|c|}{$\begin{array}{c} \pm+ \\
(N=286)\end{array}$} & \multicolumn{2}{|c|}{$\begin{array}{c} \pm- \\
(N=189)\end{array}$} \\
\hline A & 86 & 88 & 65 & 17 & 88 & 86 & 60 & 16 \\
\hline B & 84 & 90 & 84 & 38 & 78 & 91 & 77 & 43 \\
\hline C & 52 & 55 & 87 & 69 & 48 & 58 & 82 & 77 \\
\hline D & 19 & 17 & 59 & 93 & 22 & 23 & 59 & 93 \\
\hline \multirow[t]{2}{*}{$\mathrm{E}$} & 1 & 0 & 13 & 60 & 5 & 0 & 18 & 60 \\
\hline & \multicolumn{2}{|c|}{$\begin{array}{c}-\overline{+} \\
(\bar{N}=9)\end{array}$} & \multicolumn{2}{|c|}{$\begin{array}{c}-\bar{N}-61) \\
(N=6)\end{array}$} & \multicolumn{2}{|c|}{$\begin{array}{c}-+ \\
(N=10)\end{array}$} & \multicolumn{2}{|c|}{$\begin{array}{c}-- \\
(N=116)\end{array}$} \\
\hline A & 44 & 89 & 74 & 0 & 20 & 70 & 83 & 0 \\
\hline B & 22 & 78 & 69 & 7 & 30 & 70 & 79 & 4 \\
\hline $\mathrm{C}$ & 33 & 22 & 39 & 33 & 30 & 10 & 35 & 37 \\
\hline $\mathrm{D}$ & 33 & 11 & 10 & 71 & 50 & 0 & 10 & 77 \\
\hline $\mathrm{E}$ & 33 & 0 & 2 & 71 & 10 & 0 & 0 & 72 \\
\hline
\end{tabular}

TABLE 10

ROLE TYPES BY REGION

\begin{tabular}{|c|r|rr|rr|rr|rr|}
\hline \multirow{2}{*}{ Role Types } & \multicolumn{8}{|c|}{ Number } \\
\cline { 2 - 9 } & Region & \multicolumn{2}{|c|}{ North } & Border States & $\begin{array}{c}\text { Marginal } \\
\text { Deep South }\end{array}$ & $\begin{array}{c}\text { Deep Deep } \\
\text { South }\end{array}$ \\
\cline { 2 - 9 } & Race & White Negro & White Negro & White Negro & White Negro \\
\hline++ & 157 & 267 & 193 & 153 & 393 & 387 & 532 & 407 \\
+- & 6 & 37 & 10 & 24 & 18 & 72 & 36 & 88 \\
-+ & 2 & 12 & 2 & 11 & 9 & 23 & 10 & 29 \\
- & + & 45 & 143 & 83 & 119 & 162 & 336 & 305 & 449 \\
\hline Total & 210 & 459 & 288 & 307 & 582 & 818 & 883 & 973 \\
\hline
\end{tabular}


が対り得め\&化動嵒节ん被域要异人る構域

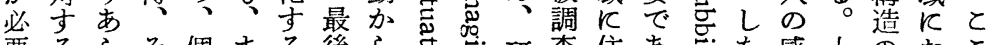
要るらそ個まる後ら志志研查住あたた感人のおと 反反われ人たがに\&すの究者んるすが情種変けで な応れを自そ、社㮩を学方個でと导つだ問化る簡 りとな型身と個会証使莺法人加る

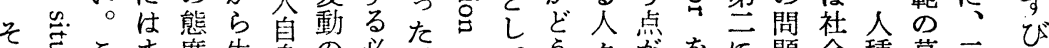

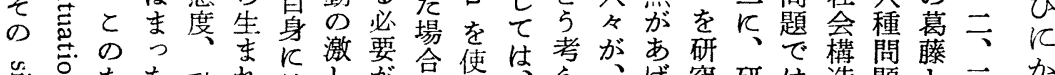

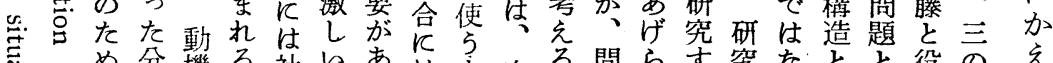

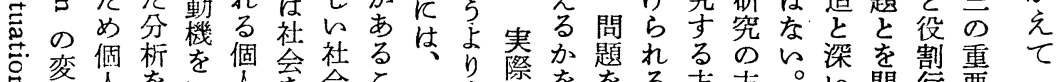

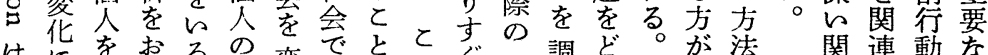
は反をおろの変でととぐの調ど。が法関連動な

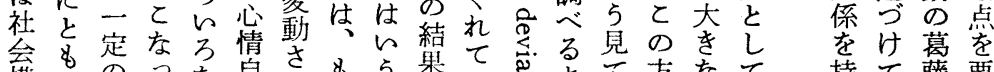

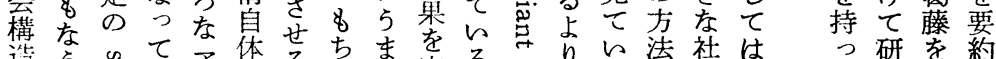

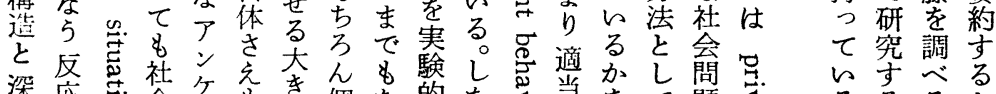

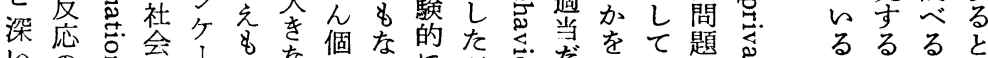

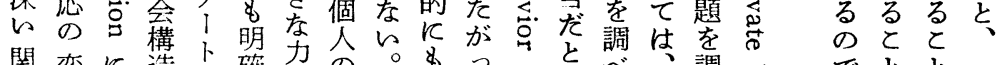

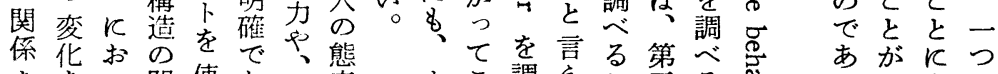

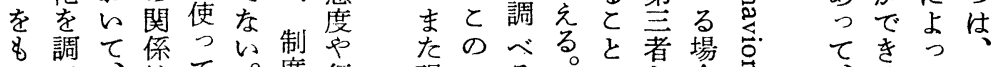

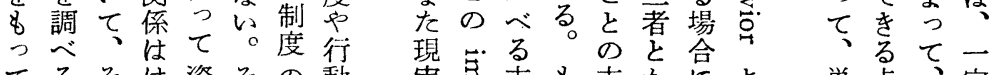

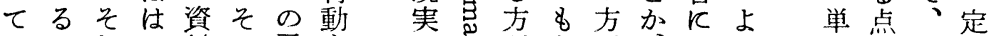

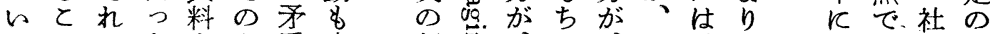
るとにををた盾変行号、ろ、地重も 個あ会地 西 西 
follows the model suggested by Samuel Stouffer.

The Sample Size and Findings: The total number or 4,228 (1,879 white college students and 2,349 Negro college students) constituted the sample for the study. These cooperating subjects were drawn from various regions of the United States. The results were analyzed quantitatively and presented graphically.

This study attempted to discover sociologically more meaningful categories for analytical purposes than either "race" or sex. It had sought to arrive at generic role types; consequently, Merton's deviant behavior typology and Stouffer's three role types were combined in making quantitative analyses of the findings. In terms of these generic role types, the various modes of adaptation to the law relative to the hit and run accident situation differed significantly between white and Negro groups. The rate for "conformists" was higher for the white than for the Negro; rates for "innovators" and "rebellion" were markebly higher for the Negro than the white; and as for "retreatism", the difference between the two groups was very slight.

Conclusion: Sociologically meaningful concepts are role types and social norms. The measurement of social norms when analyzed in terms of Merton-Stouffer concepts throws considerable lights on the differences existing between the two racial groups, white and Negro. This type of technique may provide a quick way to get at a picture of the universe of role types and, from which random samples of person: could be drawn for intensive interview. 


\title{
CONFLICIING ROLE OBLIGATIONS AND ROLE TYPES : With A Special Rer̂erence To Race Relations
}

\author{
Jitsuichi Masuoka
}

Our modern society is characterized by an extreme proliferation of groups, The bonds that bind them are, as yet, tenuous. The relationships between these diverse groups are flexible and fluid. In such a social order, the question of how the individual conforms to conflicting social norms presents a lively challenge to those students interested in theory and research.

The presence in a single society of groups varying in ethnic and racial backgrounds means generally the existence side by side of variegated social norms; some of these norms are in opposition to one another, while others are either supplementary or complementary. In the modern society it is through conflicts of customs and norms of one group with those of another that the new webb of group affiliations is constantly spun. Moreover, it is in this process that the individual is confronted with the situation of needing to make a choice between one value over another one definition over another. In this way the conflicting values are objectified and become thereby socially meaningful.

America is a "nation of nations"; she is a society with many norms and hence, the individual experiences conflicting role obligations. A typical situation of conflicting role obligations is the contact between races. Today the nature of race relations in the United Srates is such that each instance of role behavior of a person of one racial group vis-a-vis a person of another group is complicated by taking notice of race. In other words, one's racial identity is taken into account of in one's own behavior in race contact situations. Race, thus, becomes an integral part of the situation itself.

In America members of a minority group occupy a subordinate position vis-a-vis the white; as a group they are accorded differential treatment and are made to suffer from collective prejudices and discriminations. Culturally they are nearly fully assimilated, but socially they are set apart from the dominant group. It is this peculiar position in which they are compelled to remain that accounts for in part the emergence of role conflicts in race contact situations. The minority group members are Americans and yet not quite Americans. Under this condition they are led to conform to democratic norm and simultaneously they experience in varying degrees a strain toward conformity to the norms of their own group.

One of the salient features of the conflicting role obligations in race contact situations is the variability among individuals. It is this variation in individual's orientation toward social norms that is the prime interest of this present study.

It is hypothesized here that this variation is a function of the individual's perception of differential treatment accorded him as a member of a minority group, and is subject to the pressure of the state of race relations of a siven area or society. The study seeks to e amine tiose informal controls operating in a given situation through the study of role conflicts or conflicting role obligations, and as such it 